\title{
Housing Wealth and Consumption Growth: Evidence from a Large Panel of Households
}

\author{
Jie Gan ${ }^{*}$ \\ Hong Kong University of Science and Technology
}

\begin{abstract}
*Address: Department of Finance, School of Business and Management, Hong Kong University of Science and Technology, Clear Water Bay, Kowloon, Hong Kong. Email: jgan@ust.hk; Tel: 852 2358 7665; Fax: 85223581749.

I thank Anchada (Aida) Charoenrook, David Cook, Jonathan Cohn, Dwight Jaffee, Wei Jiang, Nengjiu Ju, Mike Lemmon, Enrichetta Ravina, David Robinson, Mark Seasholes, Jeremy Stein, Sheridan Titman, Neng Wang, Mungo Wilson, Wei Xiong, Chu Zhang, an anonymous referee, the editor (Matt Spiegel), and participants at Financial Intermediation Research Society Conference, Western Finance Association Conference, University of California at Berkeley, University of Texas at Austin, and Beijing University, Hong Kong University of Science and Technology, for helpful comments. Special thanks go to Suran Mansinghka and Sudipto Dasgupta for their help in obtaining the data and providing constant support throughout the project. I am grateful to Marcos Chan, Reed Louey, and Eva Siu for extensive discussions on bank mortgage lending practices and the property market in Hong Kong. I thank Wen Chau and Harry Leung for their able research assistance and Virginia Unkefer for excellent editorial assistance. The financial support from a Hong Kong RGC Research Grant (Project \# 641408) is gratefully acknowledged.
\end{abstract}




\title{
Housing Wealth and Consumption Growth: Evidence from a Large Panel Dataset of Households
}

\begin{abstract}
This paper uses a large panel dataset that tracks the housing wealth and spending behavior of 12,793 individuals in Hong Kong to study how housing wealth affects household consumption. Consumption is measured by credit card charges provided by the six largest credit card issuers in Hong Kong. Housing wealth is based on the repeat-sales price indices of nine districts in Hong Kong. District-wide housing returns mitigate the endogeneity problem arising from metropolitan-level shocks simultaneously driving housing wealth and consumption. Further, rich variation across households helps to pin down the mechanism of the observed consumption sensitivity.

Based on time-series variation within individual households, I identify a significant effect of housing wealth on consumption. A pure wealth effect can explain part of the sensitivity, since households with multiple houses tend to have much stronger consumption responses. Moreover, consistent with a relaxation of the credit constraints, households that refinance have significantly greater consumption sensitivities. However, for the majority of the households that do not refinance, the observed consumption sensitivity appears to be on account of a reduction in precautionary saving: (1) consumption sensitivity exists even in the absence of refinancing and occurs only among less leveraged households; (2) consumption responds only to unpredictable changes in housing wealth but not to predictable changes; (3) consumption responses are stronger among younger households that behave more like buffer stock savers than other age groups; (4) discretionary consumption (e.g., dining out and entertainment) responds more strongly to housing returns. Overall, the findings suggest that, even in the absence of refinancing and relaxation of the credit constraints, housing wealth can have a substantial impact on consumption growth.
\end{abstract}

JEL Classification: E21; G21

Key Words: Housing wealth, Consumption, Liquidity constraints, Precautionary saving, Credit cards, Life cycle. 
“...rising household wealth and ... greater access to that wealth.... help to explain why households in the aggregate do not appear uncomfortable with their financial position even though their reported personal savings rate is negligible."

--Testimony of Chairman Alan Greenspan Before the U.S. Senate, February 16, 2005

"The slowing of the housing market may restrain ... household spending... With homeowners no longer experiencing increases in the equity value of their homes at the rapid pace seen in the past few years ... household net worth are likely to provide less of a boost to consumer expenditures than they have in the recent past.

--Testimony of Chairman Ben Bernanke Before the U.S. Senate, July 19, 2006

\section{Introduction}

Housing is the dominant source of private wealth around the world. Housing markets, however, are volatile with large swings in prices. This has raised increasing concerns among both academics and policy makers about the economic consequences of housing price movements. One particular worry in the U.S., for example, is that with the current decline in the housing market, consumers cannot continue to borrow against their home value to fuel consumption, which could result in a larger-than-expected economic contraction.

Despite its importance, the relationship between consumption and housing wealth is not fully understood. ${ }^{1}$ The theoretical literature provides only limited guidance on how consumption responds to shocks in housing wealth. A simple formulation of the permanent-income hypothesis (PIH) suggests that the propensity to consume out of all wealth, including housing, is the annuity value of wealth changes, which implies a small effect of housing wealth on consumption (Case, Quigley, and Shiller, 2001). On the other hand, theoretical departures from PIH, motivated by its empirical failing

\footnotetext{
${ }^{1}$ There has been some recent work that undertakes the task of writing down structural general equilibrium models of housing and consumption. For example, Favilukis, Ludvigson, and Van Nieuwerburgh (2009) solve a GE model with heterogeneous households who face labor income shocks (precautionary savings motive) and housing collateral constraints in a standard incomplete markets model. There is endogenous production of capital and housing. They discuss the implications for the propensity to consume out of housing wealth. In related work Lustig and Van Nieuwerburgh $(2005,2007)$ study the housing collateral effect in a general equilibrium model. Again, households face labor income shocks (precautionary savings) and housing collateral constraints arising from a limited commitment friction. Other
} 
at both macro and micro levels, provide at least two reasons why housing wealth may have a significant impact on consumption. One involves the liquidity constraints: increases in housing wealth relax borrowing constraints, resulting in a positive consumption response to housing wealth (e.g., Campbell and Cocco, 2007). The other involves the precautionary saving motive (e.g. Carroll, 1992): a higher housing value reduces the need for precautionary saving and thus increases consumption. ${ }^{2}$ Both channels are emphasized in the testimonies of Greenspan and Bernanke quoted above. While they are not mutually exclusive, they have very different implications for the magnitude of the economic influence of a housing downturn: the liquidity constraint effect is likely to be limited to those who refinance their mortgages whereas the precautionary saving effect can potentially affect all households.

On the empirical front, how housing wealth might affect consumption has not been fully examined, primarily due to a lack of detailed household-level data. The objective of this paper is to use micro data to identify the effect of housing wealth on consumption and, based on a rich set of household characteristics, to examine the mechanism that drives this effect. In particular, I use a large panel dataset that simultaneously tracks the housing wealth and credit card spending of 12,793 individuals in Hong Kong. This dataset allows me to address some important empirical challenges to identification. First, exploiting a transactions database containing all the 1.5 million housing transactions between 1992 and 2004, I track individual housing wealth over time for nine districts in Hong Kong. Compared to metropolitan-level housing returns used in some previous studies, district-wide housing returns in the same metropolitan area are not only a more accurate measure of housing wealth, but they also avoid the endogeneity problem due to metropolitan-level economic

relevant work includes Rios-Rull and Sanchez (2009), Carroll, Otsuka, and Slacalek (2009), and Kiyotaki, Michaelides, and Nikolov (2009).

${ }^{2}$ Bhatia (1972) first points out that, with accrued capital gains, savings in other forms can be reduced and consumption increases as a result. 
shocks simultaneously affecting both housing prices and consumption. ${ }^{3}$ Second, I rely on time-series variation within individual households to identify the empirical models (through household fixed effects). This ensures that the estimates do not simply pick up unobserved household characteristics, which have been shown to be important concerns (e.g., Deaton, 1992 and Skinner 1989). Finally, I track consumption growth through households' credit card charges provided by six large credit card issuers in Hong Kong, which is arguably a more accurate measure of consumption than is food consumption or its implied total consumption as used in some previous micro studies.

The data also contain a rich set of household characteristics that helps to pin down the mechanism that drives the relationship between housing wealth and consumption. In particular, some households own more than one house, which allows me to identify a "pure" wealth effect. Further, some households face more binding liquidity constraints than others, e.g., they are close to their credit limits or cannot pay credit card bills in full, or they may have high housing leverage (i.e., high loan-to-value ratio, or high mortgage payment relative to income). Such variation facilitates a test that distinguishes between the liquidity constraints and precautionary saving. The usual story about the liquidity constraints is that a rise in housing wealth relaxes borrowing constraints, resulting in increased consumption and that such an effect should be more pronounced in more constrained households. However, unless one sells one's house, housing wealth can relax the liquidity constraints only through refinancing, which is costly and occurs infrequently (Bennet, Peach, and Peristiani, 1998). ${ }^{4}$ Thus, while a stronger consumption response among those who refinance is evidence of the credit constraints, a significant consumption response in the absence of refinancing is more consistent

\footnotetext{
${ }^{3}$ Unlike some of the metropolitan areas in the U.S. where isolated district-wise shocks may be possible, Hong Kong is a well integrated metropolitan area across different districts. A highly efficient subway system connects most parts of Hong Kong within one hour. Indeed, it is very common for people to work in one district and live in another district, commuting to work by public transportation. In the robustness checks presented later, I provide some additional evidence on this point.
} 
with a reduction of precautionary saving. Moreover, since highly leveraged households are not likely to have enough precautionary savings, i.e., they have saved less than desired, when increased housing wealth reduces the need for precautionary saving, these households are not likely to increase consumption. In other words, a reduction in precautionary saving should cause stronger consumption responses in less constrained households, opposite to the credit constraint hypothesis.

A second test that can distinguish between the liquidity constraints and precautionary saving is to examine consumption responses to predictable vs. unpredictable housing returns. It is well known that housing returns are predictable (e.g., Case and Shiller, 1995). Since under the liquidity constraint hypothesis housing serves as a collateral for borrowing, consumption should respond to all realized price increases whether they arise from the predictable or unpredictable component. ${ }^{5}$ The precautionary saving hypothesis, in contrast, implies that consumption would only respond to the unpredictable component of housing returns, to the extent that households have already factored in the predicable returns into their consumption/saving plans.

Finally, I examine some additional implications of precautionary saving. That is, consumption responses should be stronger in relatively younger households that behave more like "buffer stock savers" than do other age groups (Gourinchas and Parker, 2002) and for discretionary spending (e.g., entertainment) as opposed to non-discretionary spending.

I present two sets of results. First, I document a significant effect of housing wealth on consumption. For every $10 \%$ change in housing wealth, consumption responds by $1.7 \%$, an economically significant magnitude. Second, I document how housing wealth influences consumption. A "pure" wealth effect can explain part of the sensitivity: the consumption responses

\footnotetext{
${ }^{4}$ Bennet, Peach, and Peristiani (1998) estimate that in the U.S. the fixed closing cost is $1.5-2.5 \%$. Additional costs are also significant, including search costs, documentation costs, and prepayment penalties. The procedure and cost of refinancing has been similar in Hong Kong and in recent years seem to have become lower due to heightened bank competition.
} 
are much larger among households with more than one house. Relaxation of the credit constraints also plays a significant role, in that those households that refinance exhibit significantly larger consumption sensitivity to housing returns. However, credit constraints do not explain the consumption responses for the majority of households that do not refinance. For these households, consumption sensitivity seems to be on account of a reduction in precautionary saving: (1) there is significant consumption sensitivity even in the absence of refinancing and such sensitivity is driven by less leveraged households whose credit constraints are not binding; (2) consumption responds only to unpredictable housing returns, not to predictable returns; (3) the consumption sensitivity mainly occurs among relatively younger households that have been shown to behave more like "buffer stock consumers" (Gourinchas and Parker, 2002); (4) consumption responses are stronger for discretionary spending (e.g., dining out and entertainment). These findings highlight the importance of precautionary saving and suggest that, even in the absence of refinancing and relaxation of the credit constraints, housing wealth can have a substantial impact on consumption growth.

The paper proceeds as follows. The next section lays out my empirical design. Section 2 presents the empirical analysis. Section 3 discusses the generality of the findings. Section 4 concludes.

\section{Empirical Design}

\subsection{Empirical Challenges in Previous Studies}

There are at least three empirical challenges to identification. The first is an endogeneity problem. Since housing prices are available only at the aggregate level or at the level of metropolitan statistical areas (MSAs), the observed consumption sensitivities may be driven by economic- or MSA-wide shocks that simultaneously affect housing prices and consumption. Furthermore, the

\footnotetext{
${ }^{5}$ This is a common argument in the consumption literature, which interprets "excess" consumption sensitivity to
} 
Panel Study of Income Dynamics (PSID) data used in some studies provide self-reported home values, which can result in a spurious relationship between consumption and housing wealth when households trade up to larger houses, since these households are likely to also consume more.

The second challenge is a lack of good measures of consumption. The U.S. studies have relied on food consumption in the PSID data. This is hardly a reliable measure, not only because one has to assume constant elasticity of food consumption across households, but also because, according to Runkle (1995) and Shapiro (1984), 76-92\% of the variation in food consumption is noise.

Finally, as Skinner (1989) suggests, unobserved household heterogeneity can lead to biased estimates, a concern that can not be addressed with the short panels available for the previous studies.

\subsection{Identification Strategy and Hypothesis Development}

I identify the empirical model based on district-wise housing returns in one metropolitan area and thus circumvent the endogeneity problem arising from MSA-level shocks simultaneously affecting housing prices and consumption. Hong Kong is a single, integrated economy that spans nine residential districts, which are connected by a highly efficient subway system typically within a one-hour ride. Many people live and work in two different districts. Thus, it is not likely that district-wide shocks simultaneously drive local housing prices and consumption.

There has not been any well-established theory that explicitly models consumption with uncertain housing returns, because housing is not only an investment good, but also a consumption good, which imposes great challenge to modeling. In the Appendix, I present a simple model of intertemporal choice. I show that under the standard assumptions of life-cycle models, plus a utility function with separability between housing and non-housing consumption and exogenous housing prices, the usual Euler equation for non-housing consumption can be preserved:

predictable income shocks as evidence of a liquidity constraint. 


$$
R \beta E_{t}\left[u^{\prime}\left(C_{t+1}\right) / u^{\prime}\left(C_{t}\right)\right]=1
$$

where $R$ is the risk-free rate, $\beta$ is the discount factor, and $u^{\prime}(C)$ is the marginal utility from non-housing consumption C. Equation (1) says that housing wealth does not matter for consumption, which is the null hypothesis for my empirical tests. Based on the log-linearized Euler equation derived in the Appendix, if one allows consumption to respond to housing wealth and household income, the extended model can be written in the form:

$$
\Delta \ln \left(C_{i, t+1}\right)=a+b \Delta \ln \left(P_{i, t}\right)+\eta_{i}+\gamma_{t+1}+\text { Occupation }_{i} * \gamma_{t+1}+\varepsilon_{i, t+1},
$$

where $b$ is the estimated consumption response to housing wealth and the null hypothesis is that $b=0$; $i$ indexes households and $t$ indexes time; $\eta_{i}$ is household fixed effects, capturing time-invariant individual characteristics, such as preference for credit card usage, race, and immigration status; $\gamma_{t+1}$ is time (quarter) fixed effects, capturing economy-wide shocks. It should be noted that I do not have data on household income over time. To the extent that income growth is driven by occupation-specific wage shocks, the interactions between the dummies for occupation categories and the quarter dummies (Occupation $\left.{ }_{i} \times \gamma_{t+1}\right)$ can control for income changes.

The second part of my identification examines the mechanism that drives consumption sensitivity. I first test for a "pure" wealth effect, i.e., an effect due to changes in total life-time resources. One argument against a pure housing wealth effect, however, is that housing is a hedge again future rental increases and as long as one lives in the house, there should not be any real impact on wealth (Sinai and Souleles 2003). This argument suggests that the wealth effect should be stronger if a person owns two houses, since he/she could cash in on the wealth gain of one house and still live in the other house. Hence, we have the following hypothesis:

Hypothesis 1. If there is a pure wealth effect, the consumption responses to housing wealth should be stronger among households that own multiple houses. 
I then distinguish between credit constraints and precautionary saving. It is usually difficult to distinguish between these two because they have similar implications on the Euler Equation: both lead to steeper consumption profiles. The housing market, however, provides a unique setting to separate their effects. The usual liquidity story is that a rise in housing wealth relaxes borrowing constraints, resulting in increased consumption, and that this effect should be stronger in more constrained households. However, housing wealth relaxes the liquidity constraints only through refinancing, which is costly and occurs infrequently. Thus, credit constraints predict greater consumption-housing wealth sensitivity for those who actually refinance, whereas a significant consumption response among households that did not refinance is more consistent with a reduction of precautionary saving. Further, I identify households whose credit constraints are likely to be binding, based on credit card borrowing (i.e., how close a household is to its credit limit and whether it pays credit card bills in full) and on housing leverage (the loan-to-value ratio and mortgage affordability). These highly leveraged households are not likely to have enough precautionary saving, i.e., they save less than desired. Thus, when increased housing value reduces the need for precautionary saving, they are not likely to consume more. In other words, precautionary saving predicts that consumption responses should mostly occur in less constrained households. Hence the following two hypotheses:

\section{Hypothesis 2.}

(2a) Credit constraint: If a relaxation of the credit constraints drives the consumption-housing wealth sensitivity, consumption responses should be stronger among households that refinance.

(2b) Precautionary saving: If precautionary saving drives the consumption-housing wealth sensitivity, there are significant consumption responses even among those who do not refinance.

Hypothesis 3.

(3a) Credit constraint: If a relaxation of the credit constraints drives the consumption-housing wealth sensitivity, consumption responses should be stronger among more leveraged households. (3b) Precautionary saving: If a reduction of precautionary saving drives the consumption-housing wealth sensitivity, consumption responses should be stronger among less leveraged households. 
It is well known that housing returns are predictable (Case and Shiller, 1995 and Poterba, Weil, and Shiller, 1991). Thus a second test to distinguish between the liquidity constraints and precautionary saving is to look at consumption responses to predictable vs. unpredictable housing returns. Under the liquidity constraint hypothesis, housing serves as collateral for borrowing. Thus consumption should respond to all realized housing price appreciation, whether it is from the predictable or unpredictable component. ${ }^{6}$ The precautionary saving theory, in contrast, says that consumption should only respond to the unpredictable part of housing price increases, to the extent that predicable changes in housing wealth have already been factored into household consumption/saving plans. ${ }^{7}$ Hence we have the following hypothesis:

\section{Hypothesis 4.}

(4a) Credit constraint: If a relaxation of the credit constraints drives the consumption-housing wealth sensitivity, consumption should respond to both predictable and unpredictable components of housing price increases.

(4b) Precautionary saving: If a reduction of precautionary saving drives the consumption sensitivity, consumption should only respond to unpredictable component of housing returns.

Additionally, if precautionary saving drives the observed consumption sensitivities, then consumption responses should be stronger in younger households that behave more like "buffer stock" savers than other age groups (Gourinchas and Parker, 2002). Finally, when people feel less need to save, they might increase their discretionary spending, such as on vacations and dining out. Then discretionary consumption should be more sensitive to housing wealth.

Hypothesis 5. If a reduction of precautionary saving drives the consumption-housing wealth sensitivity, consumption should be stronger among younger household than other age groups.

Hypothesis 6. If precautionary saving drives the consumption-housing wealth sensitivity, discretionary spending should respond more to housing wealth than non-discretionary spending.

\footnotetext{
${ }^{6}$ This is a common argument in the consumption literature, which interprets "excess" consumption sensitivity to predictable income shocks as evidence of a liquidity constraint.

${ }^{7}$ It should be noted that insensitivity of consumption to predictable housing returns is also consistent with PIH. However, PIH does not predict Hypotheses 3(b), 5, or 6, which I later find empirical support.
} 


\subsection{Data and Key Empirical Measures}

There are three main sources of data. The first contains mortgage applications in a large bank in Hong Kong from 1988 to 2004, including property addresses, mortgage amount, house value, interest rates, and individual characteristics manually verified by the bank, such as age, occupation, and marital status. The bank has a network of branches throughout the city and accounts for $8 \%$ of loan originations across all districts and property types. Conversations with bank officials further confirm that there is not any specialization in the bank's lending that may lead to a selected sample.

The second data source is the government registry of all housing transactions and mortgage loans in Hong Kong during 1992-2004. This data allows me to construct district-level housing price indices and, by merging with mortgage application data based on property address, to track whether a household subsequently sells its house or refinances its mortgage. I have information on whether a household that sold its house moves to a new house only if it uses the same bank for its mortgage on the new house. Thus I drop the household from the sample if I do not have such information. ${ }^{8}$

The third data source is monthly credit card statements during 2000-2002 from six of the largest issuers with a combined market share of $75 \%$. It contains information on monthly spending, finance charges, account balances, repayments, and credit limits. I exclude retired cardholders, since their consumption decisions can be complex due to failing health or bequest motives (Ravina, 2007).

By linking credit card data with mortgage applications based on individual ID, I obtain a panel dataset of consumption, housing wealth, and household characteristics for 12,369 homeowners over 12 quarters during 2000-2002..$^{9,10}$ Table A1 in the Appendix shows that the demographics of the

\footnotetext{
${ }^{8}$ After merging with the credit card sample which covers 2000-2002, there are no such "movers" in the sample.

${ }^{9}$ For obvious confidentiality reasons, the banks provided "scrambled" Hong Kong ID numbers. Both data are scrambled in the same way so that they could be merged together.

${ }^{10}$ The mortgage data record the primary applicant's ID. While many couples share credit cards, in the cases where they do not, consumption could be underreported. Consistent estimates, however, only require the under-recording be uncorrelated with housing returns.
} 
sample is similar to that of the population, except for, not surprisingly, the very young (age 20-24) and the low-income groups (below US\$15K). Ages above 50 and especially above 60 are also under-represented since I identify homeowners based on relatively recent mortgage applications (1992-2004).

\section{Measuring Housing Wealth}

I measure housing wealth for each household by applying district-level housing price indices to initial purchase prices. Housing price indices are constructed using the repeat-sales method first suggested by Case and Shiller (1987). While repeat-sales indices have the advantage of accurately controlling for the property characteristics, this method requires a sufficient number of units to reappear. Hong Kong data are suitable for this purpose. It is one of the most densely populated cities in the world with 7 million people and a population density of 6,300 per square kilometer. Thus the housing market is commensurably large and I have on average 58K usable transactions within each district, much more than the average of $9 \mathrm{~K}$ observations at the city level in the U.S. in Case and Shiller (1987). This greatly mitigates the concern of spurious series correlation and imprecise estimates.

Figure 1 plots district-by-district price indices. Table A2 in the Appendix reports the correlation between housing returns and the stock market, as well as the correlation among district-by-district housing returns. It is interesting to note that correlation between housing returns and the stock market are generally not significant. Cross-district housing returns are generally positively correlated (the average pair-wise correlation is 0.61 ); but such correlation is much weakened ( 0.22 on average) and mostly insignificant for my sample period. I also compare the repeat-sales index with two other indices that are available in Hong Kong, namely JLL index and government index (Figure 2). It is reassuring that the overall trends of the three indices are similar. 
The JLL index is a valuation-based index based on a basket of "representative properties" and tracks the repeat-sales index very closely. The government index tends to over-sample low-to-medium properties and thus exhibits slightly lower volatility than the overall market.

\section{Measuring Consumption}

I measure consumption using credit card spending. Credit cards are widely used in Hong Kong, one of the world's financial centers. In 2002, about 22\% (US\$20 billion) of consumer spending was paid by credit cards - similar to the $20 \%$ figure in the U.S. (Chimerine, 1997). In Hong Kong, people use credit cards for food, clothing, entertainment, home appliances, and electronic products, etc., but not for housing, cars, and tuition (China Unionpay, 2005). Thus, credit card spending is a good proxy for non-durable consumption, except for electrical appliances, furniture, and personal goods, like watch and eyeglasses. Based on Hong Kong Household Expenditure Survey (HES), these durables account for roughly $7 \%$ of total credit card spending. ${ }^{11}$ Moreover, the six cards represent $75 \%$ of the market share and thus track total credit card spending for each household well.

Panel A of Table 1 compares the average credit card spending with household consumption in aggregate. ${ }^{12}$ On average, credit card spending accounts for $18 \%$ of total household non-durable consumption. Moreover, the six cards account for $17 \%$ of consumer expenditure chargeable to credit cards, which, given their market share, corresponds well with the aggregate statistics that $22 \%$ of consumer spending is charged to credit cards. Figure 3 shows that credit card spending displays the

\footnotetext{
${ }^{11}$ Hong Kong Monetary Authority conducts the survey every five years to obtain the weights for CPIs. Based on the 1999/2000 Survey, durable goods are $4.5 \%$ of total HH expenditure. Given that $38 \%$ of the nondurable goods and services (e.g., housing, education, etc.) cannot be charged to credit cards, durable goods account for $7 \%$ of credit card spending. ${ }^{12}$ Since the official statistics do not provide breakdowns of goods and services, it is a non-trivial task to back out non-durable goods and services as defined in the literature (Attanasio and Weber, 1995). I start with private consumption expenditure excluding non-durable goods. Then, based on the weights of consumption items in Household Expenditure Survey (1999/2000), I exclude housing, health, and education, which is $41 \%$ of nondurable goods and services. To get total consumer expenditure chargeable to credit cards, I add back the appropriate items of durables and services.
} 
expected characteristics of household consumption: a hump-shaped pattern over the life cycle. These comparisons suggest that credit card spending captures household consumption well.

\section{Empirical Analysis}

In this section, I conduct two sets of analyses. First, I examine whether there is any significant effect of housing wealth on consumption. Second, exploiting a rich set of household characteristics, I document the workings of such an effect. The summary statistics of variables used in analysis are presented in Panel B of Table $1 .^{13}$

\subsection{Does Housing Wealth Affect Consumption?}

Table 2 reports the baseline estimates of consumption responses to housing wealth. Column (1) includes the quarter dummies and individual household dummies. It shows a significant positive impact of housing wealth on consumption. The estimated consumption sensitivity is 0.171 . In column (2), I further include in the estimation the interactions between the individual occupation dummy and the quarter dummy to control for occupation-related income shocks. The estimate is very similar to that in column (1). These estimates imply that for every $10 \%$ (marginal) change in housing wealth, consumption changes by $1.7 \%$ - a clearly substantial impact of the housing market on the level of economic activity.

Some studies report marginal propensity to consume (MPC), which is the estimated sensitivity multiplied by the consumption-to-housing-wealth ratio. The computed MPC, however, may not be comparable across time and country since the average consumption-to-housing-wealth ratio can vary significantly across time and country. In my data, the average house value of HK $\$ 1.73$ million (US\$220K) and average annual credit card spending of $\mathrm{HK} \$ 35.8 \mathrm{~K}$ which on average is $18 \%$ 
of total spending (Panel A of Table 1). Thus the consumption-to-housing-wealth ratio is $11.5 \%$, implying a MPC of 2 cents out of one dollar. ${ }^{14}$ This relatively low MPC is due to the low consumption to housing wealth ratio - housing is expensive in Hong Kong. Thus, with expensive housing it does not take a large MPC in order for the housing market to have a substantial impact on the level of economic activity.

\subsection{How Does Housing Wealth Affect Consumption?}

\subsubsection{Testing for a "pure" wealth effect}

To test Hypothesis 1, I divide the sample into those with more than one house and those with only one house and re-estimate Equation (2). To identify those with multiple houses, I rely on the mortgage application data from the local bank, which means that I can classify an individual owning two houses only if both houses are purchased with mortgages from this local bank. Thus, I tend to under-estimate the number of families with multiple houses, which biases against finding significant differences between those with multiple houses and those without.

Consistent with a pure wealth effect, the point estimate of consumption sensitivity to housing wealth is much higher for those with more than one house (columns (3)-(4) of Table 2). ${ }^{15}$ To further test the statistical difference between the two estimates, I create a dummy variable indicating multiple houses and let it interact with housing returns. The interaction term is statistically significant at the $10 \%$ level (column (5) of Table 2).

\footnotetext{
${ }^{13}$ I report deflated housing return and consumption growth. Hong Kong does not have a CPI index that excludes housing. The Census Department publishes a CPI series (CPI(A)) based on households in the relatively low income ranges, which is less influenced by housing. The difference between CPI(A) and the overall CPI, however, is quite small.

${ }^{14}$ In Lai (2002), consumption to housing wealth ratio is calculated as total private consumption expenditure over total housing wealth. It is 0.44 in Hong Kong for 2000-2001, which is much higher than my in-sample average. The discrepancy potentially arises from two sources. First, consumption should be that of homeowners; but aggregate private consumption expenditure includes spending by the renters. Second, private consumption expenditure includes durables and services such as education, medical, and housing, as discussed earlier. Thus estimate of MPC at the aggregate level can be biased because there is not reliable statistics on consumption to housing wealth ratio in aggregate.

${ }^{15}$ It turns out that in the sample the maximum number of houses is two.
} 


\subsubsection{The effect of refinancing and household leverage}

I now test the relative importance of the liquidity constraints and the precautionary-saving motives (Hypotheses 2 and 3). The government registry of mortgage originations records two types of mortgages as related to refinancing. One is refinancing with a new loan from another bank to replace the existing loan, which can be rate refinancing (to get a lower loan rate) or cash-out refinancing. Both have consumption implications: rate refinancing through reduced monthly payments and cash-out refinancing through a one-time (large) cash award.

In Hong Kong, almost all mortgages are adjustable-rate mortgages. Banks typically charge mortgage borrowers the prime rate (which is adjustable) plus $\mathrm{x}$ percentage points (where $\mathrm{x}$ can be negative). Another bank may outbid the original bank on the " $x$ " to attract people to refinance. Figure 4 shows that the spread between the prime rate and the mortgage rate has steadily declined during the sample period. Indeed, anecdotal evidence suggests that in Hong Kong a majority of refinancing cases are for rate refinancing due to increased competition among banks. ${ }^{16}$ Probably as a response to competition, Hong Kong mortgage lenders typically impose a substantial penalty for refinancing within the first three years of loan origination. ${ }^{17}$ In my sample, since many are recently originated loans, there is a low incidence of refinancing due to the three-year refinancing penalty. ${ }^{18} \mathrm{I}$ have a total of 116 refinancing cases.

The other type of refinancing is second mortgage on top of the existing (first) mortgage. In Hong Kong, first mortgages have a maximum loan-to-value ratio of $70 \%$ and a "second mortgage" can reach a maximum of $90 \%$ loan-to-value ratio, but at a substantially higher rate. Thus, a second mortgage can be for refinancing in the usual sense or it can be a highly leveraged loan, which is

\footnotetext{
${ }^{16}$ The Surveys of Consumers from January through June 2002 described in Canner, Dynan, and Passmore (2002) also suggest that rate refinancing is the dominant type in the U.S.: about $44.8 \%$ of refinancers cashed out.

${ }^{17}$ In some mortgage contracts, there is a one-year "grace period" of refinancing with the same lender. Afterwards, the three-year restriction kicks in.
} 
typically taken out of desperation (e.g., to pay medical bills or other high-interest debt). This is consistent with the U.S. findings in Manchester and Poterba (1989) that second mortgages are generally not for consumption purposes and more than half of the borrowers use at least part of the cash to repay other debt. Therefore, I focus on the first type of refinancing in the analysis.

To examine the consumption behavior of those households who refinance, I include in Equation (2) a dummy variable, Refinance, indicating whether refinancing takes place the within previous eight quarters and let it interact with the housing return $\left(\Delta \ln \left(P_{i, t-1}\right)\right)$. Relaxation of the credit constraints predicts the interaction term to be positive (Hypothesis (2a)). Since liquidity-constrained households may be more likely to refinance, I also explicitly control for the liquidity constraints. The impact of the liquidity variables derived from credit card records (i.e., whether $75 \%$ of the credit limit is reached and whether an individual pays his/her credit card bill in full), however, may be hard wired, because when households are near their credit card limits or that they borrow more from their credit cards may indicate that they incur more credit card expenses during that period. Thus I do not include them in the estimation. But the results on refinancing do not change if I include these variables.

Consistent with Hypothesis (2a) about credit constraints, in column (1) of Table 3, the interaction term between Refinancing and housing returns is significantly positive at the $10 \%$ level. Refinancing itself is not significant, suggesting that the impact of refinancing on consumption depends on housing return which in turn determines how much cash can be obtained in refinancing. Meanwhile, the point estimate of the coefficient on housing wealth itself and its significance level are very similar to the baseline model, suggesting that there is significant consumption sensitivity even for households that do not refinance. In columns (2)-(4), I include various measures of housing leverage. Their coefficients are significantly negative (at the $10 \%$ level for the LTV ratio and the $1 \%$

\footnotetext{
${ }^{18}$ This is actually advantageous in the current setting in pinning down the impact of precautionary saving.
} 
level for mortgage affordability). The effect of refinancing on the consumption-housing wealth sensitivity remains qualitatively unchanged. Finally, in column (5) of Table 3, I examine the impact of second-mortgages. Neither Second Mortgage nor its interaction with housing return is significantly different from zero; an F-test indicates that they are not jointly significant at conventional levels.

To examine the effect of precautionary saving, I exclude households that refinance in the previous eight quarters and re-estimate the baseline model (Equation (2)). Moreover, I construct measures of the liquidity constraints that households face. The first is housing leverage. I used two commonly used leverage variables in the literature: the loan-to-value (LTV) ratio, defined as the amount of mortgage loans over housing value, and mortgage affordability, defined as the amount of outstanding mortgage over annual household income. The correlation among these two variables are not high $(0.27 \%)$ and thus they seem to capture different aspects of leverage.

The second leverage measure is based on credit card records. One is how close the individual is to the credit limit - as Gross and Souleles (2002) point out, people near their credit limits face binding credit constraints. The other variable is whether or not the individual pays credit card advances in full - given that credit card debt is an expensive source of credit, drawing upon this line of credit is an indication of being constrained. As shown in Table 1, in the sample, close to $5 \%$ of households reach $75 \%$ of their credit limit, whereas about $20 \%$ of households do not pay their credit card bills in full.

Consistent with Hypothesis (2b) about precautionary saving, consumption sensitivity exists even without refinancing (column (1) of Table 4). I further divide the sample based on whether the liquidity constraints are binding based on housing leverage above the top quartile (columns (2) - (5) 
of Table 4). ${ }^{19}$ Inconsistent with Hypothesis (3a) or credit constraints, changes in housing wealth do not have any significant impact on consumption among highly leveraged households. Rather, the observed consumption sensitivity is driven by those less leveraged households, supporting Hypothesis ( $3 b$ ) about precautionary saving. Similar results are obtained if I measure leverage using credit card records. In columns (6)-(7) and (8)-(9) of Table 4, the consumption sensitivity is only significant for those less leveraged households that are below $75 \%$ of their credit limits or that pay their credit card bills in full. ${ }^{20}$ Finally, since Hong Kong experienced a sharp price drop during the Asian financial crisis in 1998, which left those who bought at the peak with negative housing equity, I divide the sample into those with and without positive equity in columns (10)-(11) of Table 4. The effect of housing wealth is significant only if the household has positive equity. ${ }^{21}$

Overall, the results indicate that relaxation of the liquidity constraints through refinancing plays an important role in increasing the consumption sensitivity to housing wealth. However, for the majority of households that do not refinance, the observed consumption responses to housing wealth are more consistent with a reduction in the need for precautionary saving.

\subsubsection{Predictable vs. unpredictable changes in housing wealth}

This section examines consumption responses to predictable and unpredictable components of housing returns to further distinguish between the role of credit constraints and that of precautionary saving. I follow the previous literature and use lagged housing returns and variables related to housing demand including rental growth, affordability (defined as median housing price

\footnotetext{
${ }^{19}$ The results are robust to an alternative specification with interactions of housing returns with dummies for high leverage.

${ }^{20}$ I experiment with alternative cutoffs of $50 \%$ and $100 \%$ of the credit limit and the results (both the point estimates and their significance levels) remain qualitatively the same.

${ }^{21}$ I explore how housing equity interacts with my earlier leverage effects and find that the leverage effects exist only among positive-equity households. This suggests that households with negative equity, even if they are not highly leveraged, might have saved less than they would like to given the negative equity. Thus an increase in housing value does
} 
over median income), housing stock, and real GDP growth) as instruments for housing returns. I include two lags of these variables in the estimation (Table A3 in the Appendix), although the estimation is robust to alternative specification of the prediction model (e.g., using only one lag). The $\mathrm{R}$-square of the prediction equation is 0.32 . Insignificant consumption responses to predictable housing returns are therefore not likely to be due to my inability to predict housing returns. Also worth noting is that the forecast is an in-sample prediction, which potentially better captures expectation, especially given that there might be a regime shift after the Asian financial crisis.

Inconsistent with Hypothesis (4a) or credit constraints, column (1) in Panel A of Table 5 shows that consumption does not respond to the predictable component of housing wealth. In columns (2)-(11), I divide the sample based on the liquidity measures as in Table 4 . None of the sub-samples exhibits any significant consumption sensitivities to predicable housing returns. Thus, the results are inconsistent with a relaxation of the liquidity constraints but consistent with a reduction in the precautionary saving (Hypothesis $(4 b)$ ).

Panel B of Table 5 shows that consumption responds significantly to unpredictable shocks to housing returns, again consistent with Hypothesis (4b) or precautionary saving. While this is also consistent with PIH, PIH does not predict differential responses among households with different leverage. When I divided the sample based on whether the household is liquidity constrained, the consumption responses to unpredictable housing returns are driven by less constrained households (columns (2) - (11)), which is inconsistent with PIH but consistent with precautionary saving. 


\subsubsection{The life-cycle pattern of the consumption responses}

In this section, I explore consumption responses over the life cycle. If precautionary saving drives consumption sensitivity, younger households should have greater sensitivity (Hypothesis 5). ${ }^{22}$ As a first cut, I divide the sample into young (aged below 40) and old groups - a cutoff that follows Gourinchas and Parker (2002) and Cocco and Campbell (2007). In the sample, the median age is 37 and $70 \%$ of people are below 40 .

Consistent with Hypothesis 5 and as shown in columns (1) and (2) of Table 6, the effect of housing wealth is significantly positive for younger households (at the $10 \%$ level). For older households, the estimate is positive but only slightly more than half of that for the younger households and it is not statistically significant. I further check whether these two age groups face different liquidity constraints. Table 1 suggests that while young households are generally more leveraged than older households (by two out of three leverage measures), the differences between the two groups appear to be small. Thus, it is not likely that younger households being less leveraged are responsible for the results. When I sub-divide the younger sample based on the liquidity measures as in Table 3, the impact of liquidity is similar: the less-constrained sub-samples exhibit significant consumption responses to housing wealth (unreported). Thus, the liquidity constraints do not explain the differential consumption sensitivities between young and old groups. ${ }^{23}$

\footnotetext{
sensitivity. In the interest of brevity, these tests are not reported but they are available upon request.

${ }^{22}$ A difficulty in this test is that, since younger home owners may move up to a larger house in the future and thus are "short" in housing, they can have lower sensitivity to housing wealth (Campbell and Cocco, 2007). This effect would bias against the findings. There is, however, anecdotal evidence suggesting that young owners in Hong Kong are less likely to trade up to larger houses. People typically live in small houses and it is not uncommon for young people to buy houses only after they have children (which in the U.S. justifies moving to a larger house). This institutional background helps to isolate the effect of precautionary saving.

${ }^{23}$ There has been a literature suggesting that the precautionary saving motive may not vary monotonically with age. In particular, some researchers argue that elderly people can have strong precautionary saving due to late-in-life medical expenses and/or Medicaid aversion (Palumbo 1999, DeNardi, French, and Jones, 2006, and Ameriks, Caplin, Laufer, and Van Nieuwerburgh, 2008). Thus I examine the consumption sensitivity of elderly households (e.g., age $\geq 60$ ). It turns out that this group exhibits strong consumption sensitivity to housing wealth. This appears to be related to two factors: (1) elderly households have substantially stronger liquidity positions based on all four leverage measures and they have housing net worth more than double that of the other age groups; (2) there could be a pure wealth effect given that elderly
} 


\subsubsection{Discretionary v. non-discretionary consumption}

This section estimates the response of discretionary consumption to housing wealth (Hypothesis 6). In the data, two out of six card issuers keep records of one particular type of discretionary consumption, namely amount spent in restaurants and on entertainment. As shown in column (1) of Table 7, housing wealth has a significant impact on entertainment spending. More importantly, consistent with precautionary saving, the point estimate is 0.332 , about twice as large as the baseline estimate of 0.171 (Table 2 ). The difference is statistically significant $(p$ value $=0.057){ }^{24}$ There is an issue, however, in that those people who use the two cards that record entertainment spending may have other cards. Thus, their entertainment spending is possibly under-recorded. It is useful, however, to note that for this measurement error to systematically drive the results, it has to be the case that those with lower housing returns somehow tend to charge more of their entertainment spending to other cards. The test in column (2) of Table 7 further mitigates the concern of charges in other cards: when I restrict the sample to those individuals who use the two cards with entertainment spending data as their "main cards," i.e., the two cards account for at least $75 \%$ of their total credit card bills during the sample period, the main coefficient estimate remains similar. When I further divide the sample based on household leverage, consistent with the earlier findings, sensitivity of discretionary spending is driven by households with low leverage.

\footnotetext{
households are more mobile both within Hong Kong (they are not constrained by school-aged children) and outside Hong Kong (after retirement). Moreover, if they have a target bequest in housing, they are likely to consume more when that target has been met. Finally, Hong Kong has a fairly generous public health care system. All residents have access to free public medical care, although the wait line is long and many choose to purchase private insurance to pay for medical care in private hospitals. The availability of public health care may strengthen the pure wealth effect. Nevertheless, two caveats are in order. First, as discussed in Section 1.3, ages above 50 and especially above 60 are under-represented in my sample - indeed there are only 277 observations for age above 60. Second, since I have information on retirement only at the time of application, it is possible that these households have subsequently retired and thus should have been excluded from the sample. Both caveats imply that my data are not best suited to studying elderly households. In the interest of brevity, the above results are not reported but are available upon request.

${ }^{24}$ In testing for the statistical significance, I estimate seemingly unrelated regressions based on the sample for which entertainment expense is available.
} 
To summarize, I find, in the whole sample, evidence of a pure wealth effect, in that households with multiple houses have stronger consumption responses (Hypotheses 1); I also find evidence of credit constraints, in that households that refinance have stronger sensitivities (Hypothesis 2(a)). However, in the subsample of households that do not refinance, I find strong support for the precautionary-saving motive: (1) consumption responses exist without refinancing (Hypothesis 2(b)); (2) consumption responses are driven by less leveraged households (Hypothesis 3(b)); (3) consumption responds to unpredictable housing returns, but not to predictable returns (Hypothesis 4(b)); and (4) consumption responses are stronger for younger households and for discretionary spending (Hypotheses 5 and 6). Meanwhile, in this subsample, Hypotheses for the credit constraints are rejected: consumption does not respond to housing wealth for more leveraged households (Hypothesis 3(a)) or to predictable housing returns (Hypothesis 4(a)). Taken together, the evidence supports a pure wealth effect and a relaxation of the credit constraints for those households that refinance. For the majority of the households that do not refinance, the consumption sensitivity is driven by a reduction of precautionary saving, not the credit constraints.

\subsection{Robustness Checks}

\subsubsection{District-wide shocks and stock-market wealth effects}

In this section I address two alternative interpretations of the results. One is that there might be district-wide shocks driving both local housing prices and consumption. ${ }^{25}$ The other is that the stock market wealth gain can explain the results. It should be noted that several factors mitigate the above concerns. First, as discussed earlier, many Hong Kong residents work in one district and live in another one, commuting to work by a highly efficient public transportation system. Second, stock returns are at the city level (and are subsumed in time dummies), but housing returns are at the district 
level. Thus for the stock market to affect the results, it must be that households have time-varying exposure to the stock market and that those households with greater stock holdings also live in districts where housing returns are more correlated with the stock market. These are by no means obvious. In fact it is reassuring that the correlations between district-level housing returns and the stock market are generally not significant (Table A2 in the Appendix). Finally, I do not simply draw the conclusion based on regressions of consumption on housing returns; rather, I identify the mechanism through which housing wealth affects consumption, which is probably the most powerful way to deal with endogeneity.

Nevertheless, I propose the following tests to further address the above concerns. In the first test, I include interaction terms of income categories and quarter dummies as additional controls. If district-wide shocks indeed drive the results, it is likely to work through an income effect. While the occupation and quarter dummy interactions already at least partially control for this effect, this is a more direct test. This test also addresses the concern of stock market exposure, to the extent that such exposure depends on income. As reported in column (1) of Table 8, where income categories are defined based on the four quartiles of income plus a fifth category of the top ten percentile to "fine tune" the high-income category, adding interactions between income and quarter dummies neither changes the main coefficient of interest nor improves the overall fit of the model.

In the second test, I address the concern that different districts may have different exposures to overall economic conditions. For example, Hong Kong West (HK West) has the highest paid jobs, as well as the highest housing prices. If high-income people (e.g., investment bankers and senior IT workers) who both work and live in this district are more sensitive to overall economic shocks, they may drive the observed consumption sensitivity. Note that this is also the district where residents are

\footnotetext{
${ }^{25}$ The bay area of San Francisco is a good example. The technology boom raised the income of high-tech workers, who consume more and at the same time drive up local housing prices.
} 
likely to have greater stock holdings. It turns out that, as shown in column (2) of Table 8, dropping this district has little impact on the coefficient estimates.

Finally, I compute standard errors clustered at the district level. If there are systematic district wise time-varying shocks, the error terms for individuals in the same district are likely to be corrected. As reported in column (3) of Table 8, clustered standard errors are lower for the main coefficient of interest and are lower for many (but not all) other control variables. This indicates that the pair-wise errors within districts are very randomly dispersed, which is not very surprising given that many people work and live in different districts and that I already have individual household dummies in the regressions.

\subsubsection{Tenure choices and time-varying household characteristics}

Another concern in this type of study is the endogenous tenure choice. The literature has identified several factors that may affect the owning vs. renting choice, including income, tax incentives (which are largely a function of income), the correlation between income and housing returns, race, immigration status, marital status, and the number of children (e.g., Haurin, Hendershott, Wachter, 1996; Painter, Gabriel, and Myers, 2001; Davidoff, 2006). Since many of these factors are largely time invariant, especially in my sample period of three years, they are already controlled for by individual fixed effects.

There, however, may exist unmeasured time-varying factors (e.g., a big inheritance or change in family size) that could increase the incentive to buy a house or move to a larger house. It should be noted district-wise returns used in this paper greatly mitigate this concern. This is because, for time-varying household characteristics to systematically drive the results, these characteristics have to be related to both higher consumption growth and greater ability to buy a house in districts with higher returns. It is not obvious that this would happen. 
Nevertheless, I propose the following test that further addresses unobserved time-varying individual factors that may affect tenure choices or the decision to move. To the extent that such factors exist, their impact on the estimation should be stronger among those individuals who bought houses during my sample period (e.g., because they got married or had another baby). Thus, if I restrict the sample to those who have already bought a house at the beginning of the sample period, then my results should be weaker. Despite a 30\% drop in the number observations, the results remain remarkably similar, further confirming that endogenous tenure choices or time varying household characteristics do not drive the results.

\subsubsection{Other robustness checks}

I check to what extent the credit card accounts are used. It turns out that the vast majority of accounts are reasonably active: $99 \%$ of the credit card holders use their cards for at least half of the quarters during the sample period. As shown in column (1) of Table 9, dropping that $1 \%$ of infrequently used accounts, the results remain qualitatively similar (both the point estimates and its significance level).

I also examine alternative criteria in the literature. In particular, Ravina (2007) drops accounts that are ever below US\$50. While results remain robust, I lose close to half (47\%) of the observations (column (2) in Table 9). I feel this criterion is probably too restrictive for Hong Kong, because many Hong Kong residents are away during the summer. If they travel to mainland China, India, or other less developed regions where (foreign) credit cards are not commonly accepted, one may observe lower balances. Moreover, if some dips below US\$50 are exactly due to a downward adjustment of consumption in response to negative return shocks, I may have thrown away valuable information in the data. Thus I explore two alternative cutoffs: one is that spending below US $\$ 50$ occurs only once in three years (i.e., above US\$50 90\% of the time); the other is that spending below US\$ 50 occurs at 
most once per year (i.e., above US\$50 75\% of the time). The results do not change with either cutoff (columns (3) and (4) of Table 9). I also checked the subsample analysis on leverage, and the main results do not change.

Additional robustness checks include: (1) I check for non-linearity of the effect of housing wealth by adding a squared housing return in the baseline model. It turns out the squared term is insignificant whereas the linear term stay unchanged (column (5) of Table 8). (2) I check the timing of consumption responses by adding the contemporaneous housing returns and the second and third lags of housing returns in the estimation (columns (6)-(8) of Table 8). These two additional terms are not statistically different from zero, whereas the coefficient on the lagged housing returns remains qualitatively unchanged.

\section{Discussions}

\subsection{Aggregate Implications of the Micro Findings}

To facilitate comparison of my micro findings with those at the aggregate level, I explore the aggregation implication of my findings. Attanasio and Weber (1993) point out that studies based on aggregate data implicitly take logarithms of the arithmetic mean of consumption (i.e., $\left.\Delta \log \left(\frac{1}{N} \sum_{i=1}^{N} c_{i, t}\right)\right)$, which is different from the mean of $\log$ consumption (i.e., $\left.\Delta \frac{1}{N} \sum_{i=1}^{N} \log c_{i, t}\right)$ and thus can lead to biased estimates.

Since aggregating for Hong Kong yields only 11 quarters of observations which make reliable inferences unlikely, I aggregate at the district level. Thus the findings here can provide a benchmark for MSA-level studies. As shown in Table 10, aggregation in the correct way yields an elasticity (0.12) that is slightly lower than that in Table 2, but much more noisy (not statistically significant at the conventional levels). When I aggregate by taking the arithmetic means of consumption, the 
estimated elasticity is much smaller (0.012) and statistically insignificant. These findings highlight the importance of household heterogeneity and suggest that incorrect aggregation can lead to spurious results in estimation.

\subsection{Economic Significance and Comparison with the Previous Studies}

The consumption elasticity reported in this paper is higher than estimates based on aggregate U.S. data. For example, using aggregate data at the state and the country level, respectively, Case et al. (2005) and Benjamin et al. (2002) report estimates ranging from 0.05 to 0.09. Micro studies find the elasticity to be 0.04-0.06 (Lehnert, 2003; Levin, 1998; and Bostic et al., 2005). Also noteworthy is that some studies, both at the macro and the micro levels, do not find significant consumption responses at all (e..g, Elliot, 1980 and Skinner, 1989).

International evidence is more mixed: it ranges from 0.03 in Australia to $0.11-0.17$ in the 14 countries in (Case and Shiller, 2005) and to 1.2 for the UK (Campbell and Cocco, 2007). Two studies in Hong Kong covering a similar period (1982-2001) report elasticities of 0.07 to 0.14 (Lai, 2002; Cutler, 2005).

The aggregation bias discussed in the previous subsection could potentially explain part of the differences across studies. Additional differences could arise from measures of consumption and housing return, as well as household heterogeneity.

It is interesting to apply my baseline estimate of 0.17 to the U.S. economy during the housing boom of 2000-2006. Between 2000 and 2006, based on the OFHEO housing index, U.S. housing prices grew at an annualized rate of $7.7 \%$, which implies a $1.3 \%$ consumption growth. The actual consumption growth is $3.8 \%$ per year. Thus $35 \%$ of consumption growth during $2000-2006$ is driven by housing wealth gains. Another popular housing index, Case-Shiller price index, reports an 
annualized housing return of $9.16 \%$, which implies that $42 \%$ of consumption growth during 2000-2006 is due to housing wealth gains.

My estimates also suggest that, during the current downturn, every $10 \%$ drop in housing price implies a $1.7 \%$ drop in consumption. Given that consumption is about $70 \%$ of GDP, this would translate into a 1.2\% decline in GDP. Between 2007Q1 to 2008Q4, OFHEO index dropped 4.5\%, implying a moderate decline in GDP of $0.5 \%$. In contrast, Case-Shiller index dropped $24.7 \%$, which translates into a $3 \%$ decline in GDP.

\subsection{Generality of the Findings}

While the unique dataset from Hong Kong provides an excellent setting to examine the relationship between housing wealth and consumption, it is useful to discuss, at this point, how the findings may apply to the U.S. and other countries. I believe several factors make the findings in Hong Kong quite general. First, credit cards are widely used in Hong Kong ( $22 \%$ of total consumer expenditure v. $20 \%$ in the U.S.) and credit card spending is a good proxy for non-durable consumption. Second, Hong Kong's mortgage markets are well developed, which encourages home ownership. According to the Population Census 2001, half of the households lived in owner-occupied accommodations. Within these households, about half of them have outstanding mortgages. By law, people can mortgage up to $70 \%$ of the house value and, with a second mortgage, can borrow up to $90 \%$. Third, the precautionary saving motive, which is the main driver of the consumption responses to housing returns, has been documented to affect consumption in the U.S. and other countries. For example, in the U.S., late-in-life medical expenses and/or medicaid aversion is a crucial factor motivating precautionary saving and can explain the observed low spending rate of many retirees (Palumbo, 1999; DeNardi, French, and Jones, 2006; Ameriks, Caplin, Laufer, and Van Nieuwerburgh, 
2008). More generally, Gourinchas and Parker (2002) estimate that precautionary wealth accounts for $65 \%$ of U.S. household liquid wealth.

Hong Kong, however, may differ in a few dimensions from other countries and the U.S. in particular. First, refinancing is not as common in Hong Kong as in the U.S. Since refinancing increases consumption sensitivity, my results probably under-estimate the magnitude of the effect of housing wealth on consumption. Second, households in the East typically save more than households in the West, which may strengthen the effect of precautionary saving. Third, in Hong Kong mortgages have adjustable rates (ARM). The proportion of ARM vs. fixed rate mortgages (FRM could vary by country and over time (Koijen, van Hemert, and Van Nieuwerburgh, 2009). If the adjustable rates are correlated with housing prices, consumers with ARM vs. FRM could have different consumption sensitivity, through available income for consumption after mortgage payment. Thus, while the findings from Hong Kong are useful to predict a directional impact of housing wealth, the exact magnitude should not be simply extrapolated.

\section{Conclusion}

Based on a rich panel dataset of individual housing wealth and consumption, this paper identifies a significant effect of housing wealth on consumption growth. A pure wealth effect can explain part of the sensitivity, since households with multiple houses tend to have much larger consumption responses. Moreover, consistent with a relaxation of the credit constraints, households that refinance have significantly greater consumption sensitivities. However, for the majority of the households that do not refinance, the main driver of observed consumption sensitivity appears to be a reduction of precautionary saving. This is based on the following findings: (1) there exists significant consumption responses to housing wealth even in the absence of refinancing and such responses on account of less leveraged households whose borrowing constraints are not binding; (2) Consumption 
responds only to unpredictable changes in housing wealth but not to predictable changes; (3) Consumption responses are stronger among younger households that behave more like buffer stock savers than other age groups; (4) Discretionary consumption (e.g., dining out and entertainment) responds more strongly to housing returns. Overall, the findings point to the importance of precautionary saving as a cause for the effect of housing wealth on consumption and suggest that, even in the absence of refinancing and a relaxation of the credit constraints, housing wealth can have a substantial impact on consumption growth.

This study has important implications for other countries including the U.S. The property markets around the world had enjoyed unprecedented price increases till 2007. There has been hot debate on what will happen to the economy with the current "correction" in the property markets. The results in this paper illustrate a powerful channel through which housing price movements can be transmitted into the economy. In particular, they suggest that the current decline in the housing market in the U.S. is likely to have an amplifying effect on the economy due to reduced consumer spending.

The findings in this paper contribute to our understanding of the consequences of asset market "bubbles" (or large price movements). The previous literature has identified two channels through which large swings in asset prices may be transmitted into the real economy. One is a collateral channel: the bursting of asset market bubbles is likely to impair collateral values and thus diminish firms' ability to finance investment projects (Bernanke and Gertler 1989, 1990; Gan, 2006a). The other is a lending channel: the bursting of asset market bubbles impairs the financial condition of banks, since they have significant exposure to asset markets either through their real estate lending or through their direct holdings of equity and land (Bernanke, 1983; Bernanke and Gertler, 1995; Gan, 2006b). The results of this paper shed light on an additional impact of asset market bubbles; that is, 
the bursting of a housing bubble may amplify a downturn through its negative effects on household consumption. The results also confirm that monetary policy, to the extent that it may burst the bubble in the housing market, can have an amplifying impact on economic growth through its influence on consumer spending.

Future research could use the findings of this paper and formally incorporate them in a structural dynamic general equilibrium model of household consumption and saving behavior. Such a model would feature both a precautionary savings motive and housing-related credit constraints. Its structural parameters, especially the ones governing the precautionary savings and credit constraint effects, could be estimated to match the housing wealth effects uncovered in this paper. Such estimates would be instrumental in any type of policy analysis. 


\section{References}

Ameriks, J., A. Caplin, S. Laufer, and S. Van Nieuwerburgh, 2008, The Joy of Giving or Assisted Lining? Using Strategic Surveys to Separate Bequest and Precautionary Motives, Working Paper NYU Stern.

Attanasio, Orazio, and Browning, Martin, 1993a, Consumption over the Life Cycle and over the Business Cycle, American Economic Review, Vol. 85, No. 5, pp. 1118-1137.

Attanasio, Orazio, and Weber, Guglielmo, 1993b, Consumption Growth, the Interest Rate and Aggregation, The Review of Economic Studies, Vol. 60, No. 3, pp. 631-649.

Attanasio, Orazio, and Weber, Guglielmo, 1995, Is Consumption Growth Consistent with Intertemporal Optimization? Evidence from the Consumer Expenditure Survey, Journal of Political Economy, Vol. 103, No. 6, pp. 1121-1157.

Bernanke, Ben, 1983. Nonmonetary Effects of the Financial Crisis Depression, American Economic Review 73, 257-276.

Bernanke, Ben and Mark Gertler, 1995, Inside the Black Box: The Policy Transmission, Journal of Economics Perspective 9, 27-48.

Bernanke, Ben, and Mark Gertler, 1989, Agency Costs, Net Worth, and Business Fluctuations, American Economic Review 79, 14-31.

Bernanke, Ben and Mark Gertler, 1990, Financial Fragility and Economic Performance. Quarterly Journal of Economics 105, 87-114.

Bhatia, Kul B., 1971, Capital Gains and the Aggregate Consumption Function, American Economic Review 62, 866-879.

Bhatia, Kul B., 1987, Real Estate Assets and Consumer Spending, Quarterly Journal of Economics $102,437-444$.

Bostic, R., S. Gabriel, and G. Painter (2005): "Housing Wealth, Financial Wealth, and Consumption: New Evidence From Micro Data," Working Paper USC.

Browning, Martin J., Angus S. Deaton, and Margaret Irish, 1985, A Profitable Approach to Labor Supply and Commodity Demands Over the Life-Cycle, Econometrica 53, 503-544.

Campbell, John Y. and João F. Cocco, 2007, How Do House Prices Affect Consumption? Evidence From Micro Data, Journal of Monetary Economics 54 (3), 591-621.

Carroll, Christopher D., 1992, The Buffer-Stock Theory of Saving: Some Macroeconomic Evidence, Brookings Papers on Economic Activity, 61-156. 
Carroll, Christopher D., 2001, Death to the Log-Linearized Consumption Euler Equation! (And Very Poor Health to the Second-Order Approximation), Advances in Macroeconomics 1 (1), Article 6.

Carroll, Christopher D., Misuzu Otsuka, and Jirka Slacalek, 2009, How Large Is the Housing Wealth Effect? A New Approach, John Hopkins University Working Paper.

Case, Karl E. and Robert J. Shiller, 1987, Prices of Single-Family Homes Since 1970: New Indexes for Four Cities, New England Economic Review 46-56.

Case, Karl E. and Robert J. Shiller, 1989, The Efficiency of the Market for Single-Family Homes, American Economic Review, 79, 125-137.

Case, Karl E. and Robert J. Shiller, 1991, Arithmetic Repeat Sales Price Estimators, Journal of Housing Economics 1, 110-26.

Case, Karl E. John M. Quigley, and Robert J. Shiller, 2005, Comparing Wealth Effects: The Stock Market versus the Housing Market, Advances in Macroeconomics 5 (1): Article 1.

Chimerine, L., 1997, Americans in Debt: the Reality, Mastercard International.

Davidoff, Thomas, 2006, Labor Income, Housing Prices and Homeownership, Journal of Urban Economics 59, 209-235.

De Nardi, Mariacristina, French, E., and J. Jones, 2006, Differential Mortality, Uncertain Medical Expenses, and the Saving of Elderly Singles, NBER Working Paper 12554.

Elliott, J. Walter, 1980, Wealth and Wealth Proxies in a Permanent Income Model, Quarterly Journal of Economics 95, 509-535.

Engelhardt, Gary V., 1996, House Prices and Home Owner Saving Behavior, Regional Science and Urban Economics 26, 313-336.

Favilukis, J., S. Ludvigson, and S. Van Nieuwerburgh (2009): "Macroeconomic Implications of Housing Wealth, Housing Finance, and Limited Risk Sharing in General Equilibrium," Working Paper New York University.

Gan, Jie., 2006, Collateral, Debt Capacity, and Corporate Investment: Evidence from a Natural Experiment, Journal of Financial Economics, forthcoming.

Gan, Jie., 2006, The Real Effects of Asset Market Bubbles: Loan- and Firm-Level Evidence of a Lending Channel, Review of Financial Studies, forthcoming.

Gourinchas, Pierre-Olivier and Johnathan A. Parker, 2001, The Empirical Importance of Precautionary Saving, American Economic Review 91: 406-412. 
Gourinchas, Pierre-Olivier and Johnathan A. Parker, 2002, Consumption Over Life Cycle, Econometrica 70: 47-89.

Gross, David B., and Nicholas S. Souleles, 2002, Do Liquidity Constraints and Interest Rates Matter for Consumer Behavior? Evidence from Credit Card Data, Quarterly Journal of Economics, 149-185.

Hall, R. E., 1978, Stochastic Implications of the Life-Cycle Permanent Income Hypothesis: Theory and Evidence, Journal of Political Economy 86, 971-87.

Haurin, Donald R., Hendershott, Patric H., Wachter, Susan M., 1996, Wealth accumulation and housing choices of young households: an exploratory investigation, Journal of Housing Research 7: $33-57$.

Hoynes, Hilary W., and Daniel McFadden, 1997, The Impact of Demographics on Housing and Non-Housing Wealth in the United States, in Michael D. Hurd and Naohiro Yashiro (eds.), The Economic Effects of Aging in the United States and Japan, (Chicago: University of Chicago Press, 1997), 153-194.

Kiyotaki, N., A. Michaelides, and K. Nikolov, 2009, Housing Collateral and Aggregate Fluctuations, Working Paper Princeton University and London School of Economics.

Koijen, R., O. van Hemert, and S. Van Nieuwerburgh, 2009, Mortgage Timing, Journal of Financial Economics, forthcoming.

Lehnert, A., 2004, "Housing, Consumption, and Credit Constraint," Working paper Federal Reserve Board.

Lustig, H., and S. Van Nieuwerburgh, 2005, Housing Collateral, Consumption Insurance and Risk Premia: An Empirical Perspective, Journal of Finance 60 (3), 1167-1219.

Lustig, H., and S. Van Nieuwerburgh, 2007, Can Housing Collateral Explain Long-Run Swings in Asset Returns? Working Paper NYU Stern and UCLA.

Manchester, Joyce, M., and James M. Poterba, 1989, Second Mortgages and Household Saving, NBER Working Ppaer No. 2853.

Muellbauer, J. (2007): "Housing, Credit, and Consumer Expenditure," in Housing, Housing Finance, and Monetary Policy, vol. A Symposium sponsored by the Federal Reserve Bank of Kansas.

Peek, Joe, 1983, Capital Gains and Personal Saving Behavior, Journal of Money, Credit, and Banking $15,1-23$.

Palumbo, M., 1999, Uncertain Medical Expenses and Precautionary Saving Near the End of the Life cycle, Review of Economic Studies 66: 395-421. 
Painter, Gary, Stuart A. Gabriel, Dowell Myers, 2001, Race, Immigrant Status, and Housing Tenure Choice, Journal of Urban Economics 49: 150-67.

Ravina, Enrichetta, 2007, Habit Persistence and Keeping Up with the Joneses: Evidence from Micro Data, Working Paper, Columbia University.

Rios-Rull, V., and V. Sanchez, 2009, Aggregate Shocks and House Price Fluctuations, Working paper University of Minnesota.

Sinai, Todd and Nicholas Souleles, 2003, Owner-Occupied Housing as a Hedge Against Rent Risk, unpublished paper, Wharton School, University of Pennsylvania.

Skinner, Jonathan, 1989, Housing Wealth and Aggregate Saving, Regional Science and Urban Economics 19, 305-324. 
Figure 1. Housing Prices in the Nine Districts in Hong Kong (1992-2004)

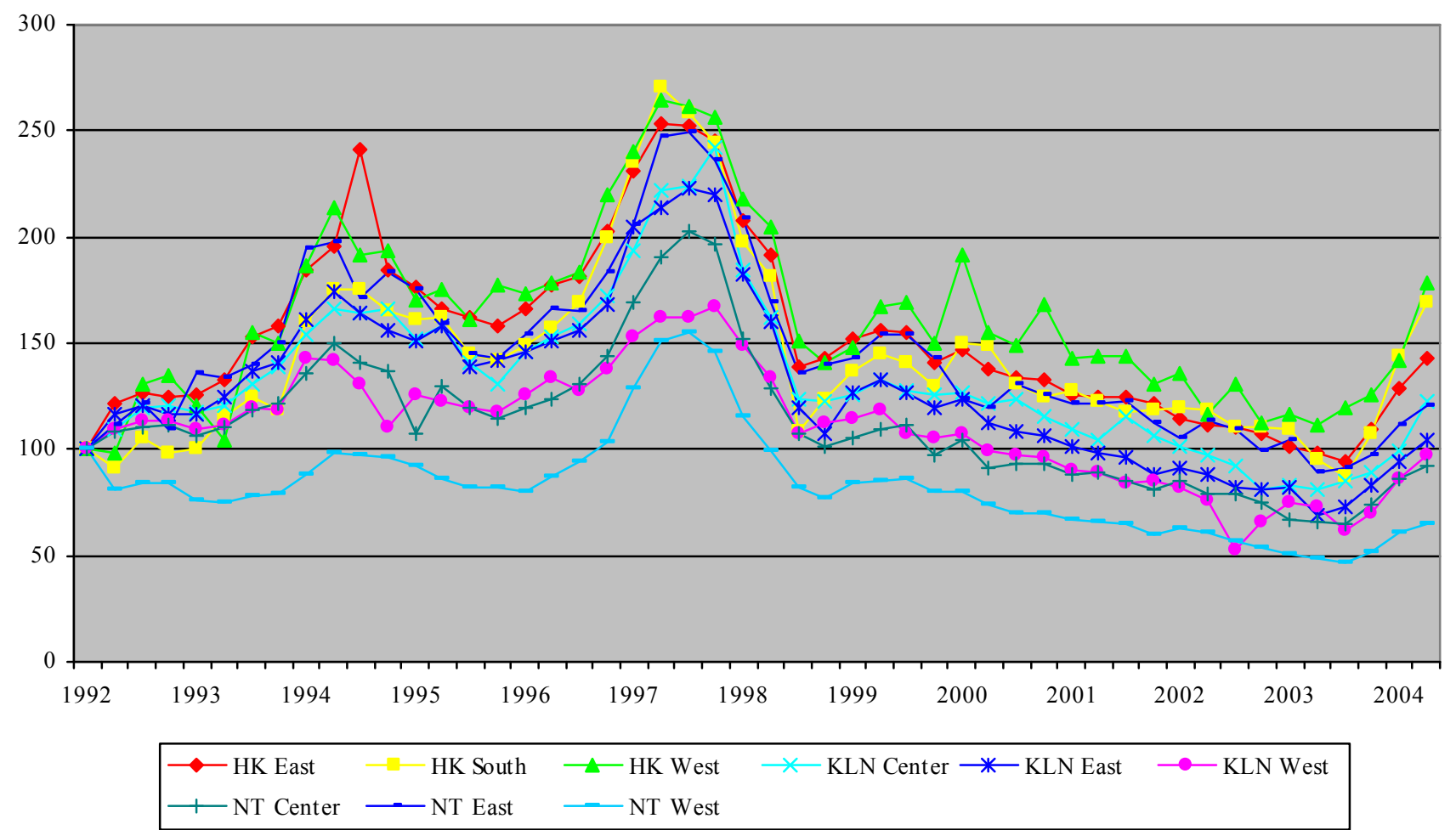

Notes: Hong Kong consists of three regions: Hong Kong Island (HK), Kowloon (KLN), and New Territory (NT). Each region is divided into three districts.

Figure 2. Repeat Sales Price Indices vs. Other Indices

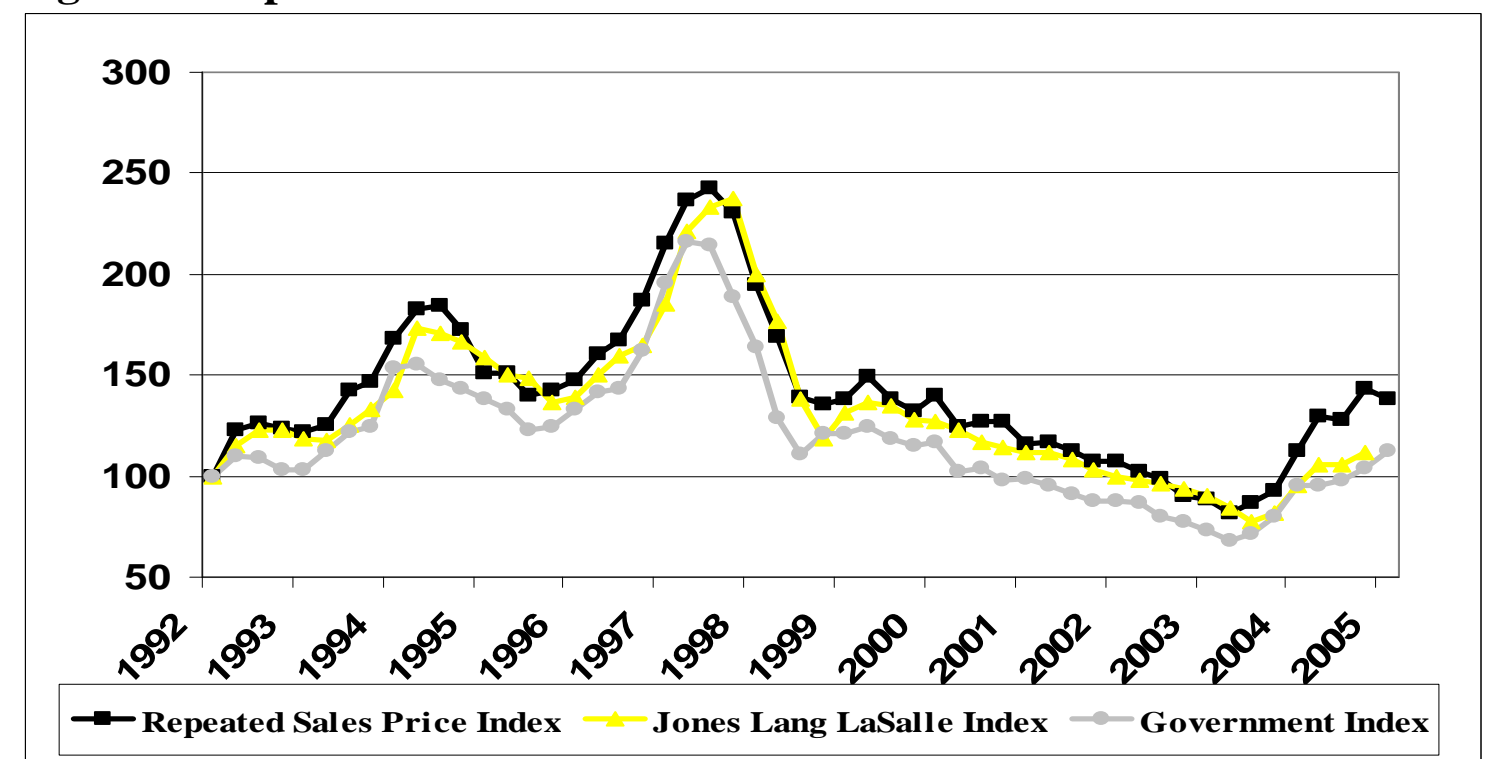

Notes: Government index is collected from the Hong Kong Property Review 2008. 


\section{Figure 3. Consumption Over the Life Cycle}

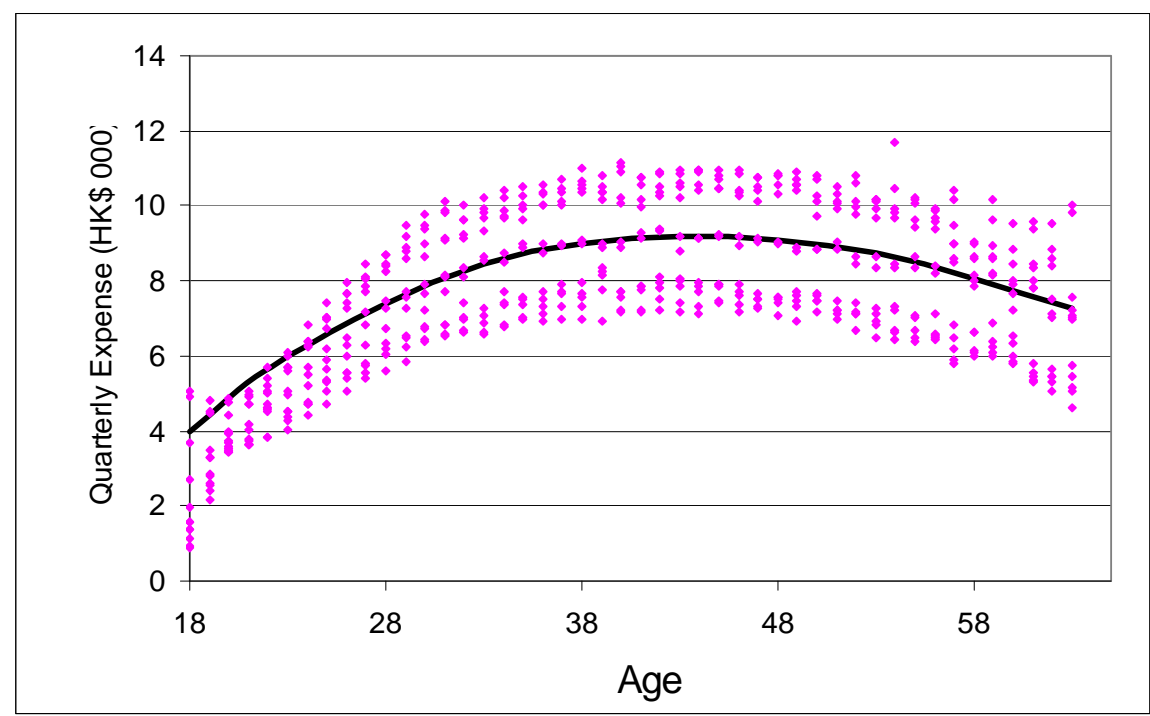

Notes: This figure plots the average expense for each age. The solid line is a trend line of the mean consumption for 10-year age groups from 18 to 68 .

Figure 4. Distribution of Mortgage Rates in Hong Kong (1998-2002)

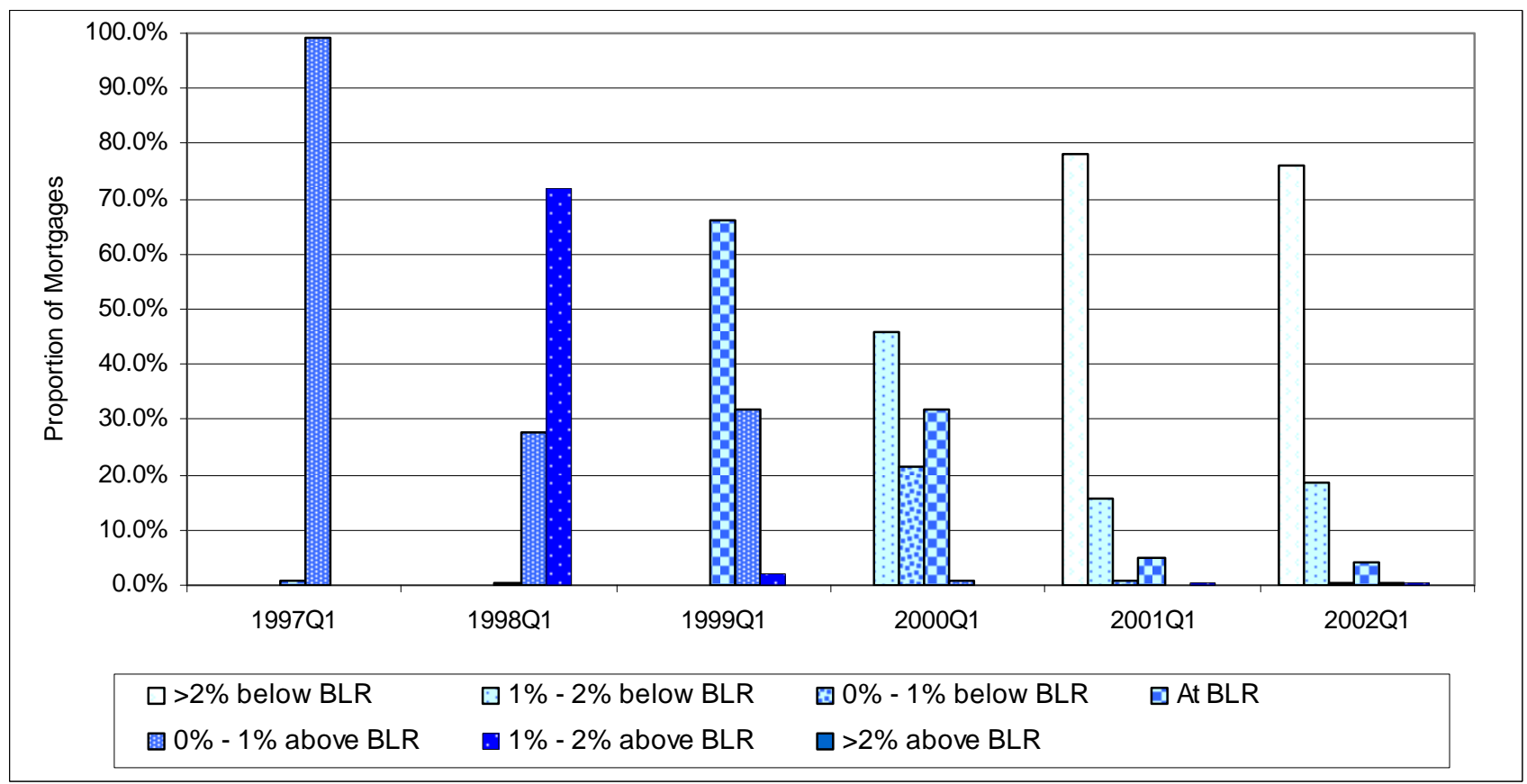

Notes: The data is from the Residential Mortgage Survey of Hong Kong Monetary Authority. BLR stands for Best Lending Rate which is the Prime Rate in Hong Kong. 
Table 1. Summary Statistics

Panel A reports average household credit card spending in the credit card sample as compared to average household non-durable consumption and household consumption chargable to credit cards based on the aggregate data. Panel B reports summary statistics of the main variables in the regressions. Consumption growth and housing returns are deflated by CPI. The LTV ratio is the ratio of the mortage loan to the housing value. Mortgage affordability is the outstanding mortgage balance over annual income.

Housing net worth is the housing value minus outstand mortgage balance. The number of households for the two age groups does not add up since age is missing for some households. Significance levels are based on two-tailed tests of differences between the two age groups; significance at the $1 \%, 5 \%$, and $10 \%$ levels is indicated by $* * *, * *$, and $*$, respectively.

Panel A. Credit Card Spending vs. Non-durable Consumption in Aggregate Data (HK\$)

\begin{tabular}{|c|c|c|c|c|c|}
\hline \multirow[b]{2}{*}{ Quarter } & \multirow{2}{*}{\multicolumn{2}{|c|}{$\begin{array}{r}\text { Household } \\
\text { Non-durable } \\
\text { Credit Card Consumption }\end{array}$}} & \multicolumn{3}{|c|}{$\begin{array}{r}\text { Household } \\
\text { Consumption }\end{array}$} \\
\hline & & & $\%$ Cards & Chargeable & $\%$ Cards \\
\hline 2000Q1 & 8,604 & 49,381 & $17 \%$ & 51,728 & $17 \%$ \\
\hline 2000Q2 & 8,613 & 51,254 & $17 \%$ & 53,690 & $16 \%$ \\
\hline 2000Q3 & 9,777 & 49,305 & $20 \%$ & 51,648 & $19 \%$ \\
\hline 2000Q4 & 9,760 & 50,907 & $19 \%$ & 53,327 & $18 \%$ \\
\hline 2001Q1 & 7,111 & 49,503 & $14 \%$ & 51,857 & $14 \%$ \\
\hline 2001Q2 & 7,726 & 51,769 & $15 \%$ & 54,230 & $14 \%$ \\
\hline 2001Q3 & 7,626 & 49,620 & $15 \%$ & 51,979 & $15 \%$ \\
\hline 2001Q4 & 7,802 & 50,380 & $15 \%$ & 52,775 & $15 \%$ \\
\hline 2002Q1 & 10,098 & 47,807 & $21 \%$ & 50,079 & $20 \%$ \\
\hline 2002Q2 & 9,801 & 48,598 & $20 \%$ & 50,908 & $19 \%$ \\
\hline 2002Q3 & 9,969 & 46,851 & $21 \%$ & 49,078 & $20 \%$ \\
\hline 2002Q4 & 7,618 & 47,231 & $16 \%$ & 49,476 & $15 \%$ \\
\hline Average & 8,709 & 49,384 & $18 \%$ & 51,731 & $17 \%$ \\
\hline
\end{tabular}

Panel B: Summaries Statistics of Variables used in the Empirical Analysis

\begin{tabular}{|c|c|c|c|c|c|c|c|c|c|}
\hline & \multicolumn{3}{|c|}{ Whole Sample } & \multicolumn{3}{|c|}{ Age $<=40$} & \multicolumn{3}{|c|}{ Age $>40$} \\
\hline & Mean & Median & $\overline{\text { s.d. }}$ & Mean & Median & $\overline{\text { s.d. }}$ & Mean & Median & $\overline{\text { s.d. }}$ \\
\hline$\Delta \log ($ Consumption $)$ & -0.115 & -0.065 & 1.428 & -0.119 & -0.072 & 1.443 & -0.107 & -0.055 & $\overline{1.400}$ \\
\hline$\Delta \log ($ Housing Wealth $)$ & -0.023 & -0.020 & 0.087 & -0.021 & -0.026 & 0.086 & -0.024 & -0.026 & 0.088 \\
\hline Age & 37.832 & 37.000 & 7.020 & & & & & & \\
\hline \multicolumn{10}{|l|}{ Leverage related variables } \\
\hline LTV ratio & 0.850 & 0.799 & 0.451 & $0.876 * * *$ & 0.815 & 0.449 & 0.804 & 0.764 & 0.450 \\
\hline Mortgage affordability & 2.819 & 2.788 & 1.114 & $2.930 * * *$ & 2.901 & 1.086 & 2.626 & 2.579 & 1.135 \\
\hline$\%$ Households reaching $75 \%$ of credit limit & 0.043 & & & $0.042 * * *$ & & & 0.043 & & \\
\hline$\%$ of Households not paying credit card bill in fu & 0.200 & & & $0.210 * * *$ & & & 0.184 & & \\
\hline$\%$ of Households with positive home equity & 0.745 & & & $0.730 * * *$ & & & 0.769 & & \\
\hline Total Number of Observations & 76,206 & & & 48,188 & & & 28,018 & & \\
\hline Total Number of Individual Households & 12,793 & & & 7,950 & & & 3,232 & & \\
\hline
\end{tabular}


Table 2. Housing Wealth and Consumption

This table presents OLS estimates of the effect of housing wealth on consumption. The dependent variable is the change in the log of consumption. $\Delta \log$ (Housing Wealth) $)_{t-1}$ is the lag of the change in the log housing value. Multiple Houses is a dummy variable indicating the household has more than one houses. Robust standard errors are in parentheses.

Significance at the $1 \%, 5 \%$, and $10 \%$ levels is indicated by $* * *, * *$, and $*$, respectively.

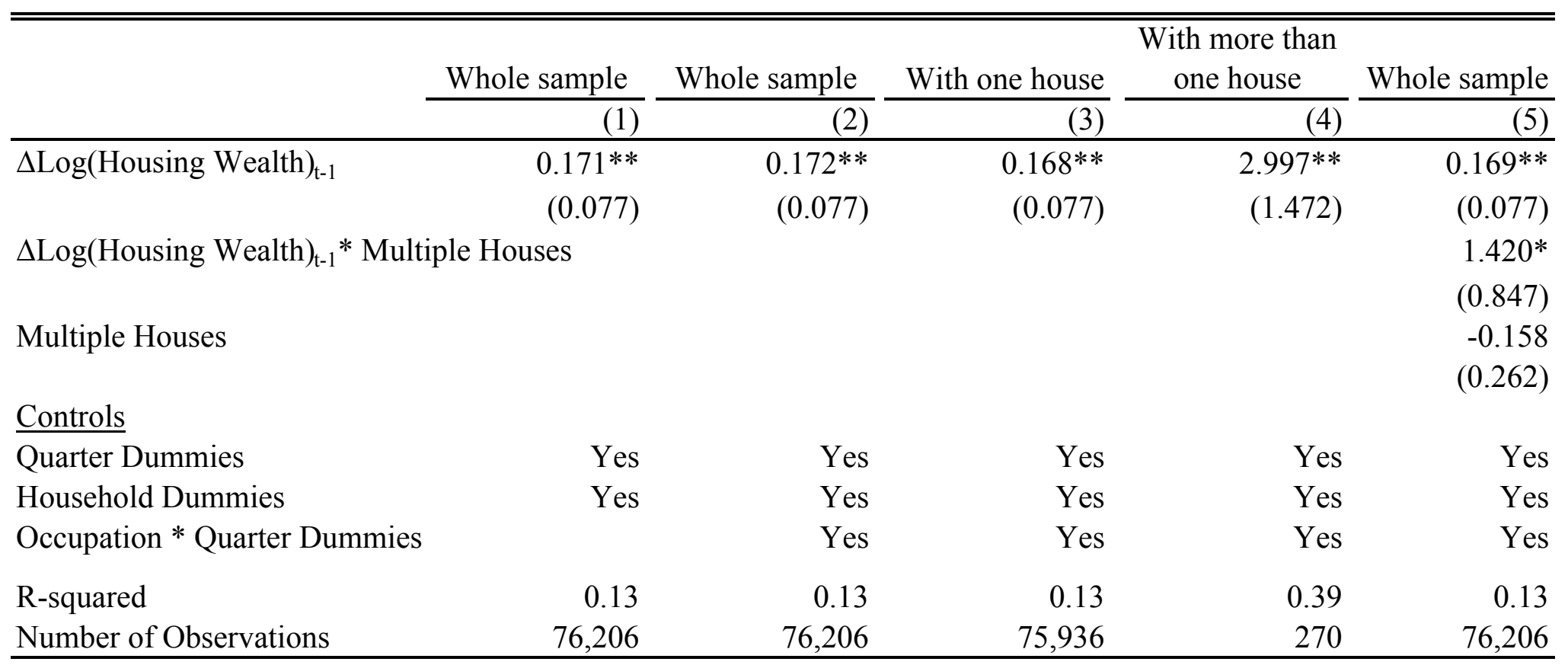


Table 3. The Effect of Refinancing

This table presents the effect of refinancing on the consumption-housing wealth sensitivity. The dependent variable is the change in the log of consumption. $\Delta \log$ (Housing Wealth)t-1 is the lag of the change in log housing value. Refinancing is a dummy variable indicating refinancing in the previous eight quarters. Second Mortgage is a dummy variable indicating whether the household has a second mortgage in the previous eight quarters. The LTV ratio is the ratio of the mortage loan to the housing value. Mortgage affordability is the outstanding mortgage balance over annual income. Robust standard errors are in parentheses. Significance at the $1 \%, 5 \%$, and $10 \%$ levels is indicated by $* * *, * *$, and $*$, respectively.

\begin{tabular}{|c|c|c|c|c|c|}
\hline & $(1)$ & $(2)$ & $(3)$ & $(4)$ & $(5)$ \\
\hline \multirow[t]{2}{*}{$\Delta \log (\text { Housing Wealth })_{\mathrm{t}-1}$} & $0.172 * *$ & $0.171 * *$ & $0.171 * *$ & $0.173 * *$ & $0.173 * *$ \\
\hline & $(0.077)$ & $(0.077)$ & $(0.078)$ & $(0.078)$ & $(0.078)$ \\
\hline \multirow[t]{2}{*}{$\Delta \log (\text { Housing Wealth })_{t-1} *$ Refinancing } & $21.914 *$ & $21.929 *$ & $21.980 *$ & $21.990^{*}$ & $22.959 *$ \\
\hline & $(12.279)$ & $(12.283)$ & $(12.408)$ & $(12.408)$ & (11.999) \\
\hline \multirow[t]{2}{*}{ Refinancing } & 0.105 & 0.106 & 0.108 & 0.109 & 0.089 \\
\hline & $(0.292)$ & $(0.292)$ & -0.292 & $(0.292)$ & $(0.303)$ \\
\hline \multirow[t]{2}{*}{ LTV ratio } & & $-0.032 *$ & & $-0.029 *$ & $-0.029 *$ \\
\hline & & $(0.017)$ & & $(0.017)$ & $(0.017)$ \\
\hline \multirow[t]{2}{*}{ Mortgage affordability } & & \multicolumn{2}{|c|}{$-0.211^{* * *}$} & $-0.204 * * *$ & $-0.204 * * *$ \\
\hline & & & $(0.072)$ & $(0.072)$ & $(0.072)$ \\
\hline \multirow[t]{2}{*}{$\Delta \log (\text { Housing Wealth })_{\mathrm{t}-1} *$ Second Mortgage } & & & & & -3.135 \\
\hline & & & & & $(9.923)$ \\
\hline \multirow[t]{2}{*}{ Second Mortgage } & & & & & 0.063 \\
\hline & & & & & $(0.344)$ \\
\hline \multicolumn{6}{|l|}{ Controls } \\
\hline Quarter Dummies & Yes & Yes & Yes & Yes & Yes \\
\hline Household Dummies & Yes & Yes & Yes & Yes & Yes \\
\hline Observations & 76,206 & 76,070 & 75,657 & 75,655 & 75,655 \\
\hline R-squared & 0.13 & 0.13 & 0.13 & 0.13 & 0.13 \\
\hline
\end{tabular}




\section{Table 4. Housing Wealth and Consumption in the Absence of Refinancing}

This table presents the consumption sensitivity to housing wealth for those households who do not refinance. The dependent variable is the change in the $\log$ of consumption. $\Delta \log$ (Housing Wealth)t-1 is the lag of the change in the log housing value. Refinancing is a dummy variable indicating refinancing in the previous eight quarters. The LTV ratio is the ratio of the mortage loan to the housing value. Mortgage affordability is the outstanding mortgage balance over annual income. Housing net worth is the housing value minus outstand mortgage balance. Robust standard errors are in parentheses.

Significance at the $1 \%, 5 \%$, and $10 \%$ levels is indicated by $* * *, * *$, and $*$, respectively.

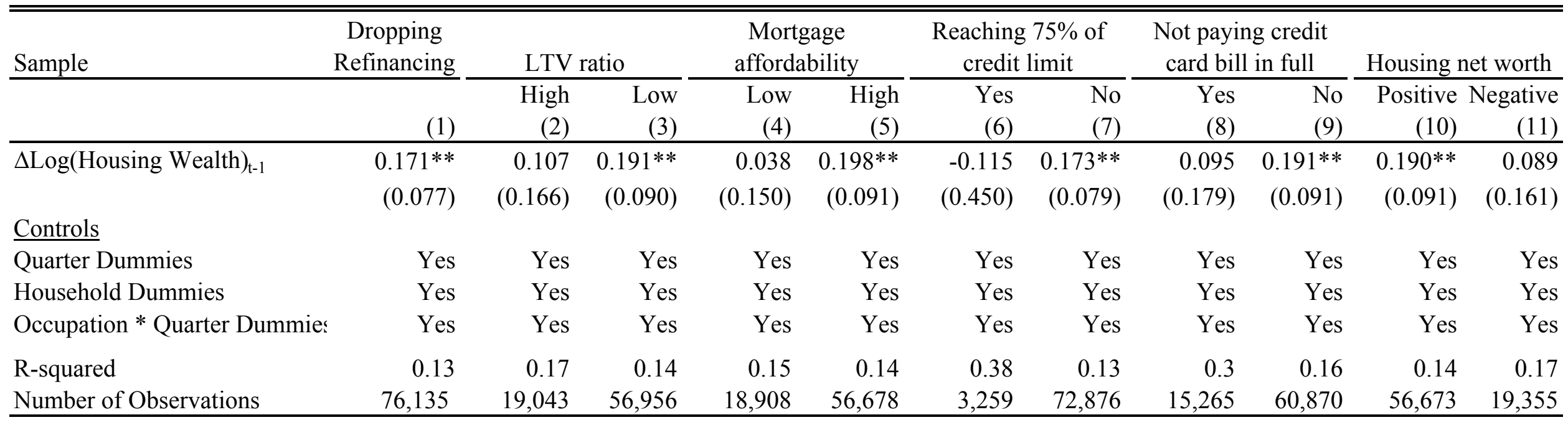


Table 5. Consumption Responses to Predictable and Unpredicable Changes in Housing Wealth

This table presents consumption responses to predictable vs. unpredictable housing returns. In Panel A, the models are estimated using instrumental variables. Instruments include two lags of housing returns, real interest rates, rental growth, affordability (defined as median housing price over median income), housing stock, and real GDP growth). The models are estimated using two-stage least square regressions. Robust standard errors are in parentheses. In Panel B, The unpredictable change in housing wealth is the residual from the first stage regression in Panel A. The LTV ratio is the ratio of the mortage loan to the housing value. Mortgage affordability is the outstanding mortgage balance over annual income. Housing net worth is the housing value minus outstand mortgage balance. Standard errors are obtained through bootstrapping to account for the sampling variations in generating unpredicted housing returns. Significance at the $1 \%, 5 \%$, and $10 \%$ levels is indicated by $* * *, * *$, and $*$, respectively.

\begin{tabular}{|c|c|c|c|c|c|c|c|c|c|c|c|}
\hline \multirow{3}{*}{ Sample } & $\begin{array}{l}\text { Whole } \\
\text { sample }\end{array}$ & \multicolumn{2}{|c|}{ LTV ratio } & \multicolumn{2}{|c|}{$\begin{array}{l}\text { Mortgage } \\
\text { affordability }\end{array}$} & \multicolumn{2}{|c|}{$\begin{array}{l}\text { Reaching } 75 \% \text { of } \\
\text { credit limit }\end{array}$} & \multicolumn{2}{|c|}{$\begin{array}{l}\text { Not paying credit } \\
\text { card bill in full }\end{array}$} & \multicolumn{2}{|c|}{ Housing net worth } \\
\hline & & High & $\overline{\text { Low }}$ & Low & High & Yes & No & Yes & No & Positive & Negative \\
\hline & (1) & (2) & (3) & (4) & (5) & (6) & (7) & (8) & (9) & (10) & (11) \\
\hline
\end{tabular}

Panel A: Predictable Changes in Housing Wealth

Predicted $\Delta \log ($ Housing Wealth)

0.111

0.322

0.162

$-0.091$

$\begin{array}{ll}0.167 & -0.959\end{array}$

0.136

$-0.105$

0.193

0.196

0.286

Quarter Dummies

Household Dummies

(0.139)

$(0.342)$

(0.143)

$(0.307)$

(0.157)

(0.712)

Yes

Yes

Yes Yes

Yes

Yes
Yes

Yes Yes

Yes

Yes

Yes

$(0.142)$

$(0.347)$

Yes

Yes

Yes
Yes

\section{R-squared}

0.13

Yes

Yes

Yes

Yes

Yes

Yes

Yes

Yes

(0.159)

(0.143)

0.38

0.13

0.14
57,027

$18,931 \quad 56,726$

3,259

72,947

Yes
0.3

Yes

Yes

0.16

$15,278 \quad 60,928$

Yes Yes

Number of Observations
Panel B: Unpredictable Changes in Housing Wealth

\begin{tabular}{lrrrrrrrrrrr} 
Unpredicted $\Delta \log (\text { Housing Wealth) })_{1-1}$ & $0.190^{*}$ & 0.082 & $0.195^{*}$ & 0.145 & $0.289^{*}$ & 0.259 & $0.208^{*}$ & 0.195 & $0.213^{*}$ & $0.188^{*}$ & 0.064 \\
& $(0.099)$ & $(0.189)$ & $(0.125)$ & $(0.186)$ & $(0.132)$ & $(0.675)$ & $(0.126)$ & $(0.219)$ & $(0.132)$ & $(0.119)$ & $(0.184)$ \\
Quarter Dummies & Yes & Yes & Yes & Yes & Yes & Yes & Yes & Yes & Yes & Yes & Yes \\
Occupation * Quarter & Yes & Yes & Yes & Yes & Yes & Yes & Yes & Yes & Yes & Yes & Yes \\
Household Dummies & Yes & Yes & Yes & Yes & Yes & Yes & Yes & Yes & Yes & Yes & Yes \\
R-squared & 0.13 & 0.16 & 0.14 & 0.15 & 0.14 & 0.38 & 0.13 & 0.3 & 0.16 & 0.14 & 0.16 \\
Number of Observations & 71,451 & 18,863 & 52,479 & 17,204 & 53,725 & 2,998 & 68,453 & 14,315 & 57,136 & 52,209 & 19,162 \\
\hline
\end{tabular}


Table 6. Housing Wealth and Consumption: Life Cycle Patterns

This table presents the consumption sensitivity to housing wealth for different age groups. The dependent variable is the change in the log of consumption. $\Delta \log \left(\right.$ Housing Wealth) $\mathrm{t}_{\mathrm{t}}$ is the lag of the change in the log housing value. Robust standard errors are in parentheses. Significance at the $1 \%, 5 \%$, and $10 \%$ levels is indicated by $* * *, * *$, and $*$, respectively.

\begin{tabular}{lrr}
\hline \hline & Age below 40 & Age above 40 \\
\cline { 2 - 3 } \cline { 3 - 3 } & $(1)$ & $(2)$ \\
\hline$\Delta \log (\text { Housing Wealth })_{\mathrm{t}-1}$ & $0.166^{*}$ & 0.099 \\
& $(0.101)$ & $(0.139)$
\end{tabular}

\section{$\underline{\text { Controls }}$}

Quarter Dummies

Household Dummies

Occupation * Quarter Dummies

Yes

Yes

Yes

Yes

R-squared

0.13

Number of Observations

48,188

Yes

Yes

0.15

26,037 


\section{Table 7. Responses of Discretionary Consumption}

This table presents the sensitivity of discretionary spending to housing wealth. The dependent variable is discretionary expenses including restraurant and entertainment spending. Only 2 out of 6 card issuers report this category of expense. In column (2) the sample is restricted to those who charge at least $75 \%$ of their total credit card spending to these two cards. The LTV ratio is the ratio of the mortage loan to the housing value. Mortgage affordability is the outstanding mortgage balance over annual income. Housing net worth is the housing value minus outstand mortgage balance. Robust standard errors are in parentheses. Significance at the $1 \%, 5 \%$, and $10 \%$ levels is indicated by $* * * * *$, and $*$, respectively.

\begin{tabular}{|c|c|c|c|c|c|c|c|c|c|c|c|c|}
\hline \multirow[t]{2}{*}{ Sample } & \multirow{2}{*}{$\begin{array}{r}\text { Whole } \\
\text { sample }\end{array}$} & \multirow{2}{*}{$\begin{array}{r}>75 \% \\
\text { Usage } \\
\end{array}$} & \multicolumn{2}{|c|}{ LTV ratio } & \multicolumn{2}{|c|}{$\begin{array}{l}\text { Mortgage } \\
\text { affordability }\end{array}$} & \multicolumn{2}{|c|}{$\begin{array}{l}\text { Reaching } 75 \% \text { of } \\
\text { credit limit }\end{array}$} & \multicolumn{2}{|c|}{$\begin{array}{l}\text { Not paying credit } \\
\text { card bill in full }\end{array}$} & \multicolumn{2}{|c|}{ Housing net worth } \\
\hline & & & $\begin{array}{r}\text { High } \\
\text { (3) } \\
\end{array}$ & $\begin{array}{r}\text { Low } \\
(4)\end{array}$ & $\begin{array}{r}\text { Low } \\
(5)\end{array}$ & $\begin{array}{r}\text { High } \\
(6) \\
\end{array}$ & $\begin{array}{r}\text { Yes } \\
(7) \\
\end{array}$ & $\begin{array}{l}\text { No } \\
(8) \\
\end{array}$ & $\begin{array}{r}\text { Yes } \\
(9) \\
\end{array}$ & $\begin{array}{r}\text { No } \\
(10) \\
\end{array}$ & $\begin{array}{r}\text { Positive } \\
(11) \\
\end{array}$ & $\begin{array}{r}\text { Negative } \\
(12) \\
\end{array}$ \\
\hline Controls & & & & & & & & & & & & \\
\hline Occupation * Quarter Dummies & Yes & Yes & Yes & Yes & Yes & Yes & Yes & Yes & Yes & Yes & Yes & Yes \\
\hline R-squared & 0.19 & 0.15 & 0.25 & 0.2 & 0.24 & 0.19 & 0.61 & 0.19 & 0.44 & 0.21 & 0.2 & 0.26 \\
\hline Number of Observations & 12,291 & 6,147 & 3,263 & 9,016 & 3,012 & 9,168 & 347 & 11,944 & 2,276 & 10,015 & 8,980 & 3,301 \\
\hline
\end{tabular}


Table 8. Robustness Checks

This table presents robustness checks. Robust standard errors are in parentheses. Significance at the $1 \%, 5 \%$, and $10 \%$ levels is indicated by $* * *, * *$, and $*$, respectively.

\begin{tabular}{|c|c|c|c|c|c|c|c|c|}
\hline & Whole sample & $\begin{array}{l}\text { Dropping } \\
\text { HK West } \\
\end{array}$ & Whole sample & $\begin{array}{c}\text { Already bougth } \\
\text { house at } \mathrm{t}=0\end{array}$ & Whole sample & Whole sample & Whole sample & Whole sample \\
\hline & $\begin{array}{l}(1) \\
(1)\end{array}$ & (2) & $(3)$ & $(4)$ & $(5)$ & $(6)$ & $(7)$ & $(8)$ \\
\hline$\Delta \log (\text { Housing Wealth })_{t-1}$ & $\begin{array}{r}0.162^{* *} \\
(0.078)\end{array}$ & $\begin{array}{r}0.194 * * * \\
(0.080)\end{array}$ & $\begin{array}{r}0.172 * * * \\
(0.053)\end{array}$ & $\begin{array}{r}0.189^{* *} \\
(0.092)\end{array}$ & $\begin{array}{r}0.181^{* *} \\
(0.078)\end{array}$ & & $\begin{array}{r}0.206^{* *} \\
(0.087)\end{array}$ & $\begin{array}{r}0.210^{* *} \\
(0.100)\end{array}$ \\
\hline$[\Delta \log (\text { Housing Wealth })]^{2}$ & & & & & $\begin{array}{r}0.169 \\
(0.128)\end{array}$ & & & \\
\hline$\Delta \log (\text { Housing Wealth })_{t}$ & & & & & & $\begin{array}{r}0.028 \\
(0.043)\end{array}$ & $\begin{array}{r}0.067 \\
(0.046)\end{array}$ & $\begin{array}{r}0.082 \\
(0.050)\end{array}$ \\
\hline$\Delta \log (\text { Housing Wealth })_{\mathrm{t}-2}$ & & & & & & & $\begin{array}{r}0.030 \\
(0.039)\end{array}$ & $\begin{array}{r}0.011 \\
(0.074)\end{array}$ \\
\hline$\Delta \log (\text { Housing Wealth })_{\mathrm{t}-3}$ & & & & & & & & $\begin{array}{l}-0.011 \\
(0.057)\end{array}$ \\
\hline \multicolumn{9}{|l|}{ Controls } \\
\hline Quarter Dummies & Yes & Yes & Yes & Yes & Yes & Yes & Yes & Yes \\
\hline District-Clustered Standard Errors & No & No & Yes & No & No & No & No & No \\
\hline R-squared & 0.13 & 0.13 & 0.13 & 0.1 & 0.13 & 0.13 & 0.13 & 0.13 \\
\hline Number of Observations & 75,675 & 74,229 & 76,204 & 54,290 & 76,206 & 76,206 & 74,088 & 74,088 \\
\hline
\end{tabular}


Table 9. Additional Robustness Checks: Inactive Accounts

This table presents the robustness of the results to dropping inactive accounts based on various criteria. Robust standard errors are in parentheses. Significance at the $1 \%, 5 \%$, and $10 \%$ levels is indicated by ***,**, and *, respectively.

\begin{tabular}{|c|c|c|c|c|}
\hline & $\begin{array}{l}\text { Positive spending at } \\
\text { least } 50 \% \text { of the times }\end{array}$ & $\begin{array}{l}\text { Spending always } \\
\text { above USD50 }\end{array}$ & $\begin{array}{l}\text { Spending below } \\
\text { USD50 at most } \\
\text { once in three years }\end{array}$ & $\begin{array}{l}\text { Spending below } \\
\text { USD50 at most } \\
\text { once per year }\end{array}$ \\
\hline & $(1)$ & $(2)$ & $(3)$ & $(4)$ \\
\hline \multirow[t]{2}{*}{$\Delta \log (\text { Housing Wealth })_{\mathrm{t}-1}$} & $0.182 * *$ & $0.141 * *$ & $0.162 * *$ & $0.140 * * *$ \\
\hline & $(0.077)$ & $(0.067)$ & $(0.068)$ & $(0.029)$ \\
\hline \multicolumn{5}{|l|}{ Controls } \\
\hline Quarter Dummies & Yes & Yes & Yes & Yes \\
\hline Household Dummies & Yes & Yes & Yes & Yes \\
\hline Occupation * Quarter Dummies & Yes & Yes & Yes & Yes \\
\hline Observations & 75,659 & 40,648 & 53,230 & 66,990 \\
\hline R-squared & 0.13 & 0.11 & 0.11 & 0.11 \\
\hline
\end{tabular}


Table 10. Aggregate Implications

This table investigates and aggregate implications of the findings. The aggregation is done at the district level. Robust standard errors are in parentheses. Significance at the $1 \%, 5 \%$, and $10 \%$ levels is indicated by $* * *, * *$, and *, respectively.

\begin{tabular}{|c|c|c|}
\hline & \multicolumn{2}{|c|}{ Dependent variable } \\
\hline & \multirow{2}{*}{$\begin{array}{l}\text { Correct Aggregation } \\
\qquad(\Delta \Sigma \ln C t)\end{array}$} & $\begin{array}{l}\text { Per-Capital Consumption } \\
\text { Aggregation }(\Delta \ln (\Sigma C t)\end{array}$ \\
\hline & & (2) \\
\hline \multirow[t]{2}{*}{$\overline{\Delta \log (\text { Housing Wealth })_{\mathrm{t}-1}}$} & 0.120 & 0.012 \\
\hline & $(0.089)$ & $(0.027)$ \\
\hline Quarter Dummies & Yes & Yes \\
\hline Observations & 99 & 99 \\
\hline R-squared & 0.89 & 0.75 \\
\hline
\end{tabular}




\section{Appendix}

I show that the standard Euler equation for consumption holds in a setting with housing. Similar to Iacoviello (2004), I make the following assumptions:

(1) Preferences: Households derive utility from both non-durable consumption $C$ and housing $H$ (priced at $P$ ). Preferences are time additive and separable between housing and non-housing consumption such that per period utility is given by: $U\left(C_{t}, H_{t}\right)=u\left(C_{t}\right)+j v\left(H_{t}\right)$, where $j$ is the relative weight on housing services in the utility function.

(2) Endowment: Households receive a random endowment $Y_{t}$ each period.

(3) Financial Assets: Households invest its savings, $B_{t}$, in a single financial asset with constant risk-free return $R$. Households can borrow and lend at the risk-free rate.

(4) Housing does not depreciate and housing consumption can be frictionlessly adjusted.

The household maximizes its lifetime utility given by:

$$
\underset{\left\{C_{t}, H_{t}\right\}}{\operatorname{Max}} E_{0} \sum_{t=0}^{+\infty} \beta^{t} U\left(C_{t}, H_{t}\right),
$$

where $\beta$ is the discount factor. The budget constraint is:

$$
C_{t}+P_{t}\left(H_{t}-H_{t-1}\right)+B_{t}=Y_{t}+R B_{t-1}=W_{t}
$$

The value function satisfies:

$$
J\left(W_{t}, H_{t-1}\right)=\max _{c_{t}, H_{t}}\left\{u\left(C_{t}\right)+j v\left(H_{t}\right)+\beta E_{t}\left[J\left(W_{t+1}, H_{t}\right)\right]\right.
$$

F.O.C with respect to $C_{t}$ and $H_{t}$, respectively, is:

$$
\begin{gathered}
u^{\prime}\left(C_{t}\right)=\beta E_{t}\left[J_{w}\left(W_{t+1}, H_{t}\right) R\right] \\
j v^{\prime}\left(H_{t}\right)=\beta E_{t}\left[J_{w}\left(W_{t+1}, H_{t}\right) R P_{t}\right]-\beta E_{t}\left[J_{H}\left(W_{t+1}, H_{t}\right)\right]
\end{gathered}
$$

The first-order derivatives of the value function with respect to the two state variables are, respectively:

$$
\begin{gathered}
J_{w}\left(W_{t}, H_{t-1}\right)=\beta E_{t}\left[J_{w}\left(W_{t+1}, H_{t}\right) R\right] \\
J_{H}\left(W_{t}, H_{t-1}\right)=\beta E_{t}\left[J_{w}\left(W_{t+1}, H_{t}\right) P_{t} R\right]
\end{gathered}
$$

Combining (A.1) and (A.3) gives the standard Euler Equation for non-housing consumption: 


$$
R \beta E_{t}\left[u^{\prime}\left(C_{t+1}\right) / u^{\prime}\left(C_{t}\right)\right]=1,
$$

Combining (A.1) - (A.4) yields the solution for housing consumption:

$$
\beta E_{t}\left[P_{t+1} u^{\prime}\left(C_{t+1}\right)\right]+j v^{\prime}\left(H_{t}\right)=P_{t} u^{\prime}\left(C_{t}\right),
$$

The above solutions are similar to Iacoviello (2004). (A.5) is simply the standard Euler equation for non-housing consumption and it says that non-housing consumption does not depend on housing wealth.

As emphasized by Attanasio and Weber (1995), household characteristics, e.g., age and labor supply choices affect housing consumption. I thus follow Attanasio and Weber (1995) and Ravina (2007) to incorporate these factors in the utility function in a multiplicative way as below:

$$
u\left(C_{i, t}\right)=\frac{C_{i, t}^{1-\rho}}{1-\rho} \exp \left(\theta^{\prime} Z_{i, t}\right),
$$

where $i$ indexes households and the first term is the usual power utility. Let $\Phi_{i, t} \equiv \theta^{\prime} Z$ and $\Phi_{i, t}$ can be parameterized as below:

$$
\Phi_{i, t} \equiv \theta^{\prime} Z_{i, t}=\operatorname{\theta age}_{i, t}+\xi_{i}+\zeta_{t},
$$

where $\xi_{i}$ is an unobservable household-specific effect and $\zeta_{t}$ is a time-varying effect.

Following the consumption literature, it is straightforward to show that the log-linearized version of (A.5) is:

$$
\Delta \ln \left(C_{i, t+1}\right)=\rho^{-1} \ln R+\rho^{-1} \ln \beta_{i}+\rho^{-1} \Delta \Phi_{i, t+1}+k+\varepsilon_{i, t+1},
$$

where $\varepsilon_{t+1}$ is the expectation error and $k$ contains second and higher moments of the variables. As is standard, both are assumed to be constant or uncorrelated with variables known at time $t$.

As in Ravina (2007), I model the discount factor as dependent on household characteristics. Thus let $\eta_{i} \equiv \rho^{-1} \ln \beta_{i}$. Also notice that in the demographic term $\Delta \Phi, \Delta a g e_{i}=0.25$ in quarterly data and the $\xi_{i}$ term is first-differenced out, we obtain $\Delta \Phi_{i, t+1}=0.25 \theta+\left(\zeta_{t+1}-\zeta_{t}\right)$. Now, Equation (A.7) can be re-written as:

$$
\Delta \ln \left(C_{i, t+1}\right)=a+\eta_{i}+\gamma_{t+1}+\varepsilon_{i, t+1},
$$

where the constant term, $a$, picks up the risk free rate $R$, the second and higher moments of consumption growth as summarized in $k$, and the change in the linear age term, i.e., $a \equiv \rho^{-1} \ln R+\rho^{-1}(0.25 \theta)+k$. The $\gamma_{t+1}$ term captures the term $\rho^{-1}\left(\zeta_{t+1}-\zeta_{t}\right)$ in the demographics. 
Log-linearized Euler Equation in (A.8) forms the null hypothesis of my empirical tests. In my empirical specification, I allow consumption to respond to housing wealth. Moreover, since the standard consumption literature includes household income in the consumption equation, I include occupation-specific changes in income, given that I do not have quarter-by-quarter household income. Thus the extended model can be written in the form:

$$
\Delta \ln \left(C_{i, t+1}\right)=a+b \Delta \ln \left(P_{i, t}\right)+\eta_{i}+\gamma_{t+1}+\text { Occupation }_{i} * \gamma_{t+1}+\varepsilon_{i, t+1},
$$

where $\Delta \ln \left(P_{i, t}\right)$ is the log change in housing prices in the previous quarter and the null is $b=0$. Occupation is the occupation category and Occupation $_{i} * \gamma_{t}$ captures time-varying income shocks driven by occupation-specific wage changes and the null is that it is zero as in Hall (1978). 
Table A1 Demographic Characteristics: Comparison with Hong Kong Census Data

\begin{tabular}{lrrr}
\hline & $\begin{array}{c}\text { Credit Card } \\
\text { Sample }\end{array}$ & $\begin{array}{c}\text { Homeowners in } \\
\text { Credit Card } \\
\text { Sample }\end{array}$ & $\begin{array}{c}\text { Hong Kong } \\
\text { Census }\end{array}$ \\
\hline $\begin{array}{l}\text { Panel A. Age Comparison } \\
20-24\end{array}$ & $7 \%$ & $1 \%$ & $9 \%$ \\
$25-29$ & $16 \%$ & $13 \%$ & $10 \%$ \\
$30-34$ & $18 \%$ & $25 \%$ & $11 \%$ \\
$35-39$ & $20 \%$ & $28 \%$ & $14 \%$ \\
$40-44$ & $17 \%$ & $17 \%$ & $13 \%$ \\
$45-49$ & $11 \%$ & $10 \%$ & $10 \%$ \\
$50-54$ & $7 \%$ & $4 \%$ & $8 \%$ \\
$55-59$ & $2 \%$ & $1 \%$ & $5 \%$ \\
$60-64$ & $1 \%$ & $0 \%$ & $5 \%$ \\
$65+$ & $1 \%$ & $0 \%$ & $15 \%$ \\
Total & $100 \%$ & $100 \%$ & $100 \%$
\end{tabular}

Panel B. Income Comparison

Homeowners

Monthly Income Annual Income Credit Card in Credit Card Hong Kong $(\mathrm{HK} \$)$ (US\$) Sample Sample Census

\begin{tabular}{lrrrr} 
Less than 10,000 & Less than 15,000 & $24 \%$ & $9 \%$ & $22 \%$ \\
$10,000-14,999$ & $15,000-22,999$ & $27 \%$ & $15 \%$ & $16 \%$ \\
$15,000-19,999$ & $23,000-30,999$ & $17 \%$ & $22 \%$ & $13 \%$ \\
$20,000-24,999$ & $31,000-37,999$ & $11 \%$ & $15 \%$ & $11 \%$ \\
$25,000-29,999$ & $38,000-45,999$ & $6 \%$ & $8 \%$ & $8 \%$ \\
$30,000-39,999$ & $46,000-61,999$ & $7 \%$ & $14 \%$ & $11 \%$ \\
$40,000-59,999$ & $62,000-91,999$ & $5 \%$ & $10 \%$ & $10 \%$ \\
$>=60,000$ & $92,000+$ & $3 \%$ & $7 \%$ & $9 \%$ \\
Total & & $100 \%$ & $100 \%$ & $100 \%$ \\
\hline
\end{tabular}


Table A2. Correlation of Housing Returns with Stock Returns and Among Districts

\begin{tabular}{|c|c|c|}
\hline Panel A Correlation & of Housing & eturn with \\
\hline & $1992-2004$ & 000-2002 \\
\hline Whole Hong Kong & 0.0578 & 0.0437 \\
\hline & $(0.6934)$ & $(0.8928)$ \\
\hline HK West & -0.0892 & 0.0029 \\
\hline & $(0.5423)$ & $(0.9929)$ \\
\hline HK South & 0.0190 & 0.2712 \\
\hline & $(0.8969)$ & $(0.3938)$ \\
\hline HK East & 0.2059 & 0.0790 \\
\hline & $(0.1557)$ & $(0.8072)$ \\
\hline NT East & 0.1102 & -0.3691 \\
\hline & $(0.4508)$ & $(0.2378)$ \\
\hline NT Center & 0.1087 & 0.2502 \\
\hline & $(0.4571)$ & $(0.4329)$ \\
\hline NT West & -0.0041 & 0.0228 \\
\hline & $(0.9777)$ & $(0.9439)$ \\
\hline KLN Center & 0.0721 & -0.5704 \\
\hline & $(0.6224)$ & $(0.0528)$ \\
\hline KLN East & 0.1220 & 0.1089 \\
\hline & $(0.4038)$ & $(0.7363)$ \\
\hline KLN West & 0.1268 & 0.5122 \\
\hline & $(0.3853)$ & $(0.0887)$ \\
\hline
\end{tabular}

Panel B Correlation of District-wise Housing Returns (1992-2004)

\begin{tabular}{|c|c|c|c|c|c|c|}
\hline HK South & $\begin{array}{r}\text { HK West } \\
0.5580 \\
(<.0001)\end{array}$ & HK South HK East NT East I & NT Center & NT West & KLN Center & KLN East Average \\
\hline \multirow[t]{2}{*}{ HK East } & 0.4970 & 0.7158 & & & & \\
\hline & $(0.0003)$ & $(<.0001)$ & & & & \\
\hline \multirow[t]{2}{*}{ NT East } & 0.3789 & $0.6048 \quad 0.5081$ & & & & \\
\hline & $(0.0073)$ & $(<.0001)(0.0002)$ & & & & \\
\hline \multirow[t]{2}{*}{ NT Center } & 0.5965 & $\begin{array}{lll}0.6548 & 0.6340 & 0.5085\end{array}$ & & & & \\
\hline & $(<.0001)$ & $(<.0001)(<.0001)(0.0002)$ & & & & \\
\hline \multirow[t]{2}{*}{ NT West } & 0.5386 & $0.7508 \quad 0.5630 \quad 0.5160$ & 0.7235 & & & \\
\hline & $(<.0001)$ & $(<.0001)(<.0001)(0.0001)$ & $(<.0001)$ & & & \\
\hline \multirow[t]{2}{*}{ KLN Center } & 0.6002 & $0.6715 \quad 0.6675 \quad 0.6634$ & 0.7365 & 0.6383 & & \\
\hline & $(<.0001)$ & $(<.0001)(<.0001)(<.0001)$ & $(<.0001)$ & $(<.0001)$ & & \\
\hline \multirow[t]{2}{*}{ KLN East } & 0.5896 & $\begin{array}{lll}0.7325 & 0.7269 & 0.6372\end{array}$ & 0.7906 & 0.6871 & 0.7659 & \\
\hline & $(<.0001)$ & $(<.0001)(<.0001)(<.0001)$ & $(<.0001)$ & $(<.0001)$ & $(<.0001)$ & \\
\hline \multirow[t]{2}{*}{ KLN West } & 0.3223 & $\begin{array}{lll}0.6647 & 0.5895 & 0.4610\end{array}$ & 0.4123 & 0.4751 & 0.4909 & 0.6032 \\
\hline & $(0.0239)$ & $(<.0001)(<.0001)(0.0009)$ & $(0.0032)$ & $(0.0006)$ & $(0.0003)$ & $(<.0001)$ \\
\hline Average & 0.5101 & $\begin{array}{lll}0.6691 & 0.6127 & 0.5347\end{array}$ & 0.6321 & 0.6115 & 0.6542 & $0.6916 \quad 0.6145$ \\
\hline \multicolumn{7}{|c|}{ Panel C Correlation of District-wise Housing Returns (2000-2002) } \\
\hline & HK West & HK South HK East NT East I & NT Center & NT West & KLN Center & KLN East Average \\
\hline \multirow[t]{2}{*}{ HK South } & 0.2662 & & & & & \\
\hline & $(0.4029)$ & & & & & \\
\hline \multirow[t]{2}{*}{ HK East } & 0.8003 & 0.3041 & & & & \\
\hline & $(0.0018)$ & $(0.3365)$ & & & & \\
\hline \multirow[t]{2}{*}{ NT East } & -0.3581 & $-0.6970-0.2443$ & & & & \\
\hline & $(0.2531)$ & $(0.0118)(0.4441)$ & & & & \\
\hline \multirow[t]{2}{*}{ NT Center } & 0.7984 & $\begin{array}{lll}0.1688 & 0.5292 & -0.2376\end{array}$ & & & & \\
\hline & $(0.0018)$ & $(0.6000)(0.0768)(0.4571)$ & & & & \\
\hline \multirow[t]{2}{*}{ NT West } & 0.5175 & $\begin{array}{llll}0.2523 & 0.1966 & -0.1407\end{array}$ & 0.6502 & & & \\
\hline & $(0.0848)$ & $(0.4288)(0.5403)(0.6628)$ & $(0.0221)$ & & & \\
\hline \multirow[t]{2}{*}{ KLN Center } & 0.2974 & $\begin{array}{lll}-0.0467 & 0.3621 & 0.3583\end{array}$ & 0.1151 & 0.1085 & & \\
\hline & $(0.3479)$ & $(0.8855)(0.2474)(0.2528)$ & $(0.7218)$ & $(0.7372)$ & & \\
\hline \multirow[t]{2}{*}{ KLN East } & 0.6027 & $\begin{array}{lll}0.4529 & 0.3981 & -0.2938\end{array}$ & 0.7732 & 0.8641 & 0.1183 & \\
\hline & $(0.0380)$ & $(0.1393)(0.1999)(0.3540)$ & $(0.0032)$ & $(0.0003)$ & $(0.7143)$ & \\
\hline \multirow[t]{2}{*}{ KLN West } & -0.2057 & $\begin{array}{llll}0.2949 & -0.0484 & -0.3311\end{array}$ & 0.0499 & 0.2157 & -0.3147 & 0.3648 \\
\hline & $(0.5212)$ & $(0.3521)(0.8813)(0.2932)$ & $(0.8776)$ & $(0.5007)$ & $(0.3192)$ & $(0.2437)$ \\
\hline Average & 0.3398 & $0.1244 \quad 0.2872-0.2430$ & 0.3559 & 0.3330 & 0.1248 & $0.4100 \quad 0.2165$ \\
\hline
\end{tabular}




\section{Table A3. Predicting Housing Returns}

This table presents the first-stage regression of the tests in Table 5. The dependent variable is the housing returns. Robust standard errors are in parentheses. Significance at the $1 \%, 5 \%$, and $10 \%$ levels is indicated by ***, **, and $*$, respectively.

\begin{tabular}{lr}
\hline \hline & $(1)$ \\
\hline Log(Rental $)_{\mathrm{t}-1}$ & $1.501^{* * *}$ \\
& $(0.050)$ \\
$\log \left(\right.$ Rental $_{\mathrm{t}-2}$ & $-1.807^{* * *}$ \\
& $(0.056)$ \\
Affordability & $\mathrm{t}-1$ \\
& $67.126^{* * *}$ \\
Affordability & $(1.839)$ \\
& $-49.998^{* * *}$ \\
Housing Return & $(1.688)$ \\
& $-0.330^{* * *}$ \\
Housing Return & $(0.002)$ \\
& $-0.235^{* * *}$ \\
Housing Stock & $(0.002)$ \\
& $-0.333^{* *}$ \\
Housing Stock & $(0.162)$ \\
GDP Growth & $1.568^{* * *}$ \\
GDP Growth & $(0.136)$ \\
R-squared & $-2.576^{* * *}$ \\
Number of Observations & $(0.067)$ \\
\end{tabular}

